
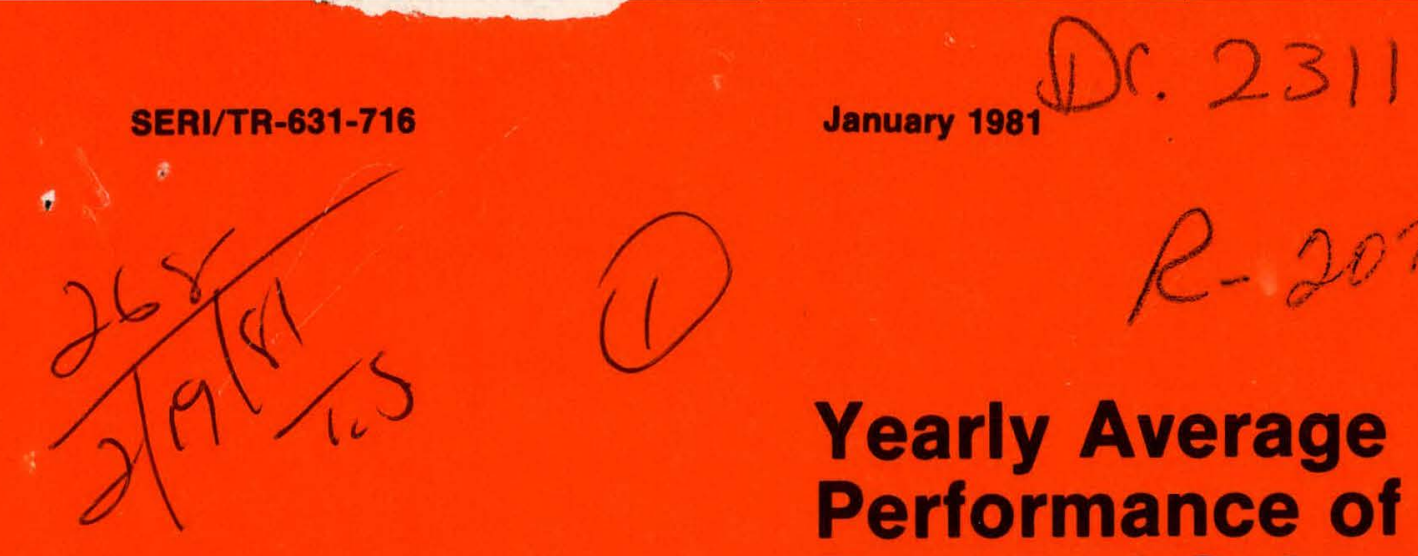

$$
\text { R- } 2071
$$

\title{
Yearly Average Performance of the Principal Solar Collector Types
}

Ari Rabl
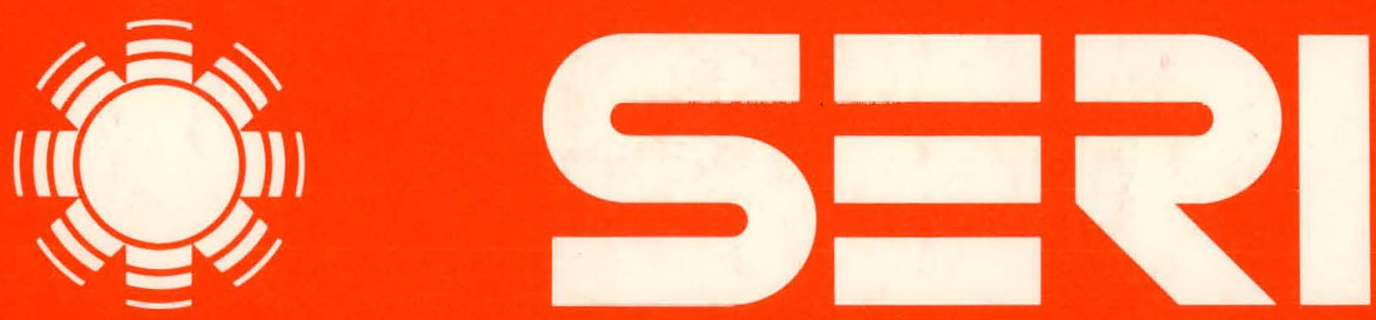

Solar Energy Research Institute A Division of Midwest Research Institute

1617 Cole Boulevard

Golden, Colorado 80401

\section{Operated for the}

U.S. Department of Energy

under Contract No. EG-77-C-01-4042 


\section{DISCLAIMER}

This report was prepared as an account of work sponsored by an agency of the United States Government. Neither the United States Government nor any agency Thereof, nor any of their employees, makes any warranty, express or implied, or assumes any legal liability or responsibility for the accuracy, completeness, or usefulness of any information, apparatus, product, or process disclosed, or represents that its use would not infringe privately owned rights. Reference herein to any specific commercial product, process, or service by trade name, trademark, manufacturer, or otherwise does not necessarily constitute or imply its endorsement, recommendation, or favoring by the United States Government or any agency thereof. The views and opinions of authors expressed herein do not necessarily state or reflect those of the United States Government or any agency thereof. 


\section{DISCLAIMER}

Portions of this document may be illegible in electronic image products. Images are produced from the best available original document. 
Printed in the United States of America Available from:

National Technical Information Service

U.S. Department of Commerce

5285 Port hoyal Road

Springfield, VA 22161

Price:

Microfiche $\$ 3,00$

Printed Copy $\$ 4.50$

\begin{abstract}
NOTICE
This report was prepared as an account of work sponsored by the United States Government. Neither the United States nor the United States Department of Energy, nor any of their employees, nor any of their contractors, subcontractors, or their employees, makes any warranty, express or implied, or assumes any legal liability or responsibility for the accuracy, completeness or usefulness of any information, apparatus, product or process disclosed, or represents that its use would not infringe privately owned rights.
\end{abstract}


SER I /TR $-631-716$

UC CATEGORY: UC-62

YEARLY AVERAGE PERFORMANCE OF THE PRINCIPAL SOLAR COLLECTOR TYPES

ARI RABL

JANUARY 1981

PREPARED IINDER TASK NO, 3471.10

\section{Solar Energy Research Institute}

A Division of Midwest Research Institute

1617 Cole Boulevard

Golden, Colorado 80401

Prepared for the

U.S. Department of Energy

Contract No. EG-77-C-01-4042 


\section{THIS PAGE \\ WAS INTENTIONALLY \\ LEFT BLANK}


This report was prepared under SERI task number 3471. I am grateful to P. Bendt and M. Collares-Pereira for stimulating discussions and to $P$. J. Eicker for information on the results of calculations done at Sandia Laboratories. I also thank H. W. Gaul for transferring intermediate results from the $\operatorname{CDC} 7600$ computer to the Hewlett-Packard 9845 calculator. I am indebted to L. Vant-Hull for a critical reading of the manuscript and for valuable comments on the central receiver. This report will be published in Solar Energy during 1981.

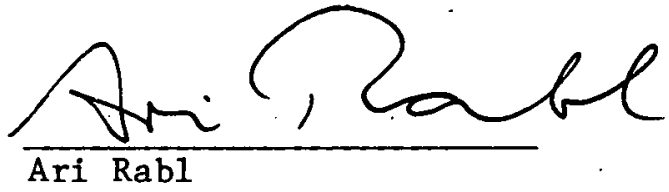

Approved for

SOLAR ENERGY RESEARCH INSTITUTE

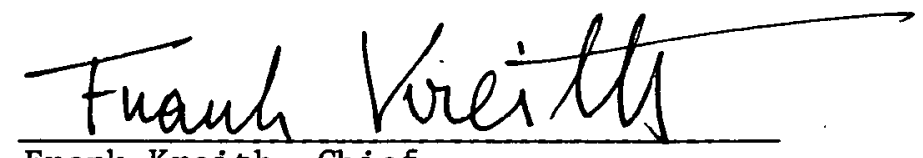

Frank Kreith, Chief

Solar Thermal Research Branch

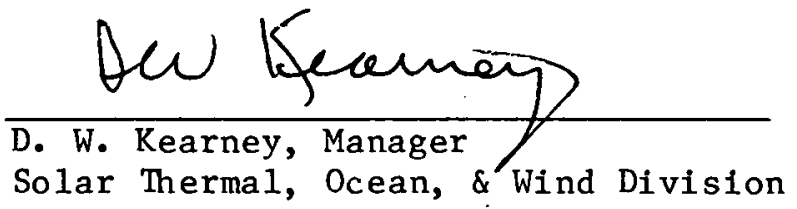




\section{THIS PAGE}

\section{WAS INTENTIONALLY \\ LEFT BLANK}


SUMMARY

\section{OBJECTIVES}

The results of hour-by-hour simulations for 26 meteorological stations are used to derive universal correlations for the yearly total energy that can be delivered by the principal solar collector types: flat plate, evacuated tubes, CPC, collectors that track about one axis, collectors that track about two axes, and central receiver.

\section{DISCUSSION}

The correlations are polynomials of first and second order in yearly average insolation, latitude, and threshold (= ratio of heat loss and optical efficiency). With these correlations the yearly collectible energy can be found by reading. a single graph and multiplying the coordinates by the collector parameters. This simple method reproduces the results of hour-by-hour computer calculations with an accuracy (rms error) of $2 \%$ for flat plates and $2 \%$ to $4 \%$ for concentratiors.

\section{CONCLUSIONS AND RECOMMENDATIONS}

This method can be applied to any system where the collectors operate yearround in such a way that no collected energy is discarded. This includes photovoltaic systems; solar-augmented industrial process heat systems; and solar thermal power systems. In addition, the method is recommended for rating collectors of different types or different manufacturers on the basis of yearly average performance. The method is also useful for evaluating the effects of collector degradation, the benefits of collector cleaning, and the gains from collector improvements (due to enhanced optical efficiency or decreased heat loss per absorber surface). For most of these applications, the method is accurate enough to replace a system simulation. 


\section{ABREGE \\ "Performances Annuelles Moyennes des Principaux Types de Capteurs Solaires"}

Les résultats des simulations d'heure en heure de 26 stations météorologiques sont utilisés pour établir des corrélations universelles de l'énergie totale annuelle pouvant être récupérée par les principaux types de.capteurs solaires: capteurs plans fixes, capteurs à tube sous vide, miroirs composés à foyer quasi-linéaire, capteurs de poursuite du soleil par rotation autour d'un ou de deux axes, et récepteurs centraux. Les corrélations sont des polynômes du premier et du second degré en ensoleillement annuel moyen, latitude et seuil (rapport entre les pertes thermiques et le rendement optique). L'énergie annuelle récupérable peut être estimée à partir de ces corrélations en consultant une seule abaque et en multipliant les coordonnées par les paramètrco du capteur. Cette simple méthode fournit les mêtues résullals yue les simulations $d$ 'heure en heure avec une précision (erreur quadratique moyonno) do $2 \%$ pour lco captcuro plano fixes et de 2 i $4 \%$ pour les concentrateurs.

Cette méthode peut être employée pour les systèmes dont les capteurs fonctionnent toute l'année sans rejet d'énergie récupérée. Cette catégorie comprend les systèmes à conversion photovoltaique, les procédés thermiques industriels à apport d'énergie solaire, et les centrales thermiques solaires.

De plus, cette méthode est recommandée pour juger des capteurs de différent type ou manufacture en fonction des performances annuelles moyennes. E11e est également utile pour évaluer les effets respectifs de la dégradation. des capteurs, de leur nettoyage, et de leur amélioration en termes d'un meilleur rendement optique ou de pertes thermiques réduites par unité de surface absorbante. Dans la plupart de ces applications, la méthode est suffisamment précise pour être utilisée à la place d'une simulation du système. 
Jährliche Durchschnittsleistung der wichtigsten Typen von Solarenergiekollektoren.

Die. Ergebnisse stündlicher Simulierungen für 26 meteorologische Stationen werden ausgewertet für die Gewinnung allgemeiner Korrelationen für die jährliche Gesamtenergie, die durch die wichtigsten Solarenergiekollektoren gewonnen werden kann.: Flachplatte, luftleere Röhren, CPC, Kollektoren mit Ein-Axen-nachfuehrung, Kollektoren mit Zwei-Axen-Nachfuehrung, und Zentralemfänger. Die Korrelationen sind Polynome erster und zweiter Ordnung in Breitengrad, jaehrlicher Direkt-Solarstrahlung und Schwelle (=Verhältnis von Wảrmeverlust und optischer Leistung.) Mit diesen Korrelationen läßt sich die jährliche speicherbare Energie finden, indem man eine einzige Kurve liest und die Koordinaten mit den Kollektor-Parametern multipliziert. Diese elnfache Methode reproduziert die Ergebnisse von stündlichen Simulierungen mit. einer Genauigkeit (rms Abweichung) von 2\% für Flachplatten und 2 bis $4 \%$ für Konzentratoren.

Diese Methode läßt sich auf jedes System anwenden, bei dem Kollektoren das ganze Jahr hindurch so betrieben werden, daß keine gesammelte Energie verloren geht. Das sind; fotovoltaische Systeme; durch Solarenergie unterstützte industrieprozessuelle Wärmesysteme; und solarthermale Kraftsysteme.

Darüber hinaus ist die Methode zu empfehlen bei der Bewertung von Kollektoren verschiedener Typen oder verschiedener Hersteller auf der Basis jährlicher Durchschnittsleistung. Die Methode is auch anwendbar beim Bewerten der Auswirkungen des Lelstungsverlusts von Kollektoren und dem Nutzen der Säuberung und Verbesserung von Kollektoren (auf Grund verstärkter optischer Leistung oder verminderten Wärmelusts pro Absorbierungsfläche). Für die meisten dieser Anwendungen ist die Methode präzise genug, daß sie eine SystemSimulierung ersetzen kann. 


\author{
RESUMEN \\ Rendimiento Promedio Anual de los Principales Tipos \\ de Colectores Solares
}

Los resultados de las simulaciones que se realizan de hora a hora para 26 estaciones meterológicas se utilizan para establecer las correlaciones universales de la energía anual total que se puede recibir por medio de los principales tipos de colectores solares: placa plana, tubo de colección al vacío, concentrador parabólico compuesto (CPC), colectores que recorren sobre un eje, colectores que recorren sobre dos ejes y un receptor central. Las correlaciones son polinomias de primer y segundo orden en insolación promedio anual, latitud y umbral (= cociente de pérdida de calor y eficiencia óptica). - Con estas correlaciones se puede calcular la energía que se puede colectar anualmente, leyendo un solo gráfico y multiplicando las coordenadas por 100 parámetros del colector. Este métudu selicillo reproduce los resultados de simulaciones realizadas de hora a hora, con precisión (error media cuadrática) de $2 \%$ para las placas planas y de 2 a $4 \%$ para 10 s concentradores.

Este método se puede aplicar a cualquier sistema en el cual los colectores están en funcionamiento todo el año de tal manera que no se descarta energía colectada. Esto incluye: los sistemas fotovoltaicos, los sistemas térmicos de proceso industrial desarrollado por energía solar y los sistemas eléctricos térmicos solares.

Además, se recomienda este método para clasificar los colectores de diferente tipo y de diferente fabricación, en base al rendimiento promedin anua $1 . F_{1}$ método también es útil para evaluar los efectos del deterioro del colector, los beneficios de la limpieza y aumentos provenientes de la mejnra de los colectores (debido al aumento de eficiencla óptica o disminución de la pérdida de calor por superficie absorbente). Para la mayoría de estas aplicaciones, el método es lo suficientemente preciso para reemplazar un sistema de simulaction. 
TABLE OF CONTENTS

\section{$\underline{\text { Page }}$}

1.0 Introduction...................................... 1

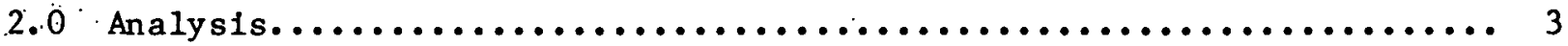

2.1 Lessons from Previous Work......................... 3

2.2 As sumptions....................................... 5

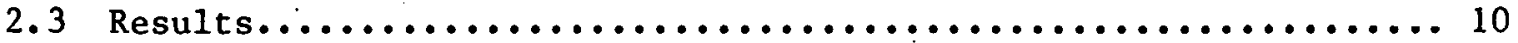

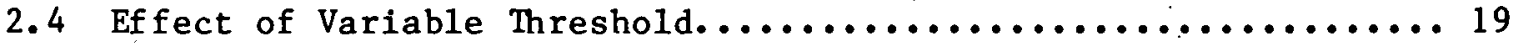

2.5 Additional Comments............................... 21

3.0 Conclusion-Examples................................ 25

3.1 . Photovoltaic Systems............................ 25

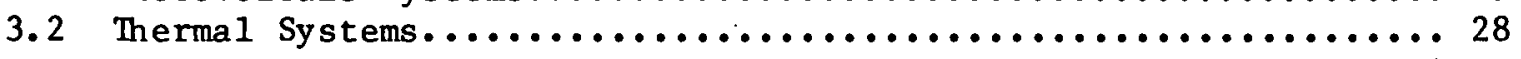

4.0 Reference....................................... 35

Appendix - Tubular Collectors and Incidence Angle Modifiers............. AI 
THIS PAGE

\section{WAS INTENTIONALLY LEFT BLANK}


LIST OF FIGURES

$\underline{\text { Page }}$

2-1 The 26 SOLMET Stations............................. 4

2-2 Yearly Collectible Energy for Flat Plate................... 12

2-3 Yearly Collectible Energy for CPC....................... 13

2-4 Yearly Collectible Energy for Concentrator Tracking

about East-West Axis................................. 14

2-5 Yearly Collectible Energy for Concentrator Tracking

about Horizontal North-South Axis....................... 15

2-6 Yearly Collectible Energy for Concentrator Tracking

about Polar Axis................................... 16

2-7 Yearly Collectible Energy for Concentrator with Two-Axis Tracking... 17

2-8 Yearly Collectible Energy for Central Receiver................. 18

2-9 Distribution of the Values of Insolation and Latitude

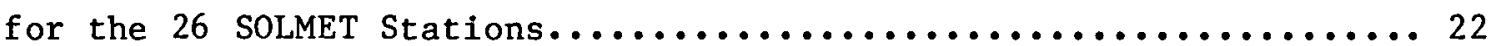

2-10. Yearly Average Direct Normal Irradiance During Daytime for the

United States.................................... 23

2-11 Correlation between Yearly Average Clearness Index and Yearly

Average Direct Normal. Solar Irradiance During Daytime........... 24

3-1 Yearly Total Solar Irradiation Available for Flat Plate,

Concentrator with East-West Tracking Axis, Concentrator with

Two-Axis Tracking, and Central Receiver, as a Function of Average

Direct Normal Irradiance.............................. 26

3-2 Yearly Collectible Energy Versus Average Difference between Fluid Temperature and Ambient for Typical Collectors: (a) $I=0.6 \mathrm{~kW} / \mathrm{m}^{2}$

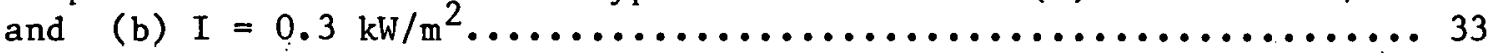

A-1 Incidence Angle Modifiers for Several Evacuated-Tubular Collectors.. Al

A-2 Yearly Collectible Energy for SUNPAK ${ }^{m}$ SERIES................ A2

A-3 Yearly Collectible Energy for SUNPAK ${ }^{m}$ Drainable...................

A-4 Yearly Collectible Energy for General Electric................ A4 


\section{THIS PAGE}

\section{WAS INTENTIONALLY \\ LEFT BLANK}


LIST OF TABLES

Page

2-1 Assumptions of the Mode1............................... 5

2-2 Validation of the Model for Flat-Plate Collector................ 12

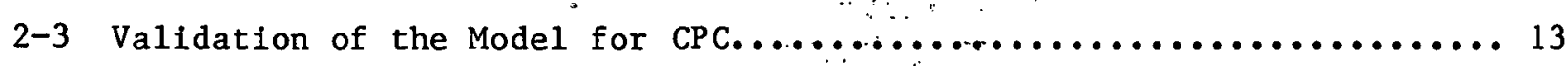

2-4 Validation of the Model for Concentrator with East=west Tracking Axis............................................ 14

2-5 Validation of the Model for Concentrator with Horizontal North-South

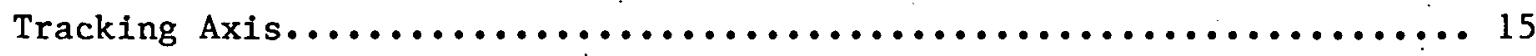

2-6 Validation of the Model for Concentrator with Polar Tracking Axis..... 16

2-7 Validation of the Model for Concentrator with Two-Axis Tracking....... 17

2-8 Errors Due to Threshold Variation for Flat-Plate Collector.......... 20

3-1 Typical Collector Parameters Assumed for Comparison in Fig. 3-2...... 32. 
Blank

xiv 


\section{NOMENCLATURE}

A collector aperture area

$\mathrm{A}_{\mathrm{g}} \quad$ ground area covered by collector array

$c_{p} \quad$ specific heat at constant pressure $\left(\mathrm{J} / \mathrm{g}^{\circ} \mathrm{C}\right)$

C geometric concentration ratio

$\mathrm{F} \quad$ heat transfer factor $=\left\{\begin{array}{lll}1 & \text { if } \mathrm{T}_{\mathrm{col1}}=\mathrm{T}_{\mathrm{r}} \\ \mathrm{F}^{\prime} & \text { if } \mathrm{T}_{\mathrm{col1}}=\mathrm{T}_{\mathrm{f}} \\ \mathrm{F}_{\mathrm{R}} & \text { if } \mathrm{T}_{\mathrm{col1}}=\mathrm{T}_{1 \mathrm{n}}\end{array}\right.$

$F^{\prime} \quad$ collector efficiency factor

$F_{R}$. heat removal factor

$\mathrm{H}$ daily total hemispherical irradiation on horizontal surface

$\mathrm{H}_{\mathrm{O}} \quad$ extraterrestrial irradiation on horizontal surface

I yearly average direct normal irradiance $\left(\mathrm{kW} / \mathrm{m}^{2}\right)$ during daylight hours, also called beam irradiance or direct normal insolation.

$\mathrm{I}_{\mathrm{b}}$ hourly beam irradiance, also called direct normal insolation

$\mathrm{I}_{\mathrm{d}}$ diffuse irradiance

$I_{h} \quad$ hemispherical irradiance

$I_{\text {col1 irradiance incident on collector aperture }}$

$\mathrm{K}(\theta) \quad \eta_{\mathrm{O}}(\theta) / n_{\mathrm{O}}(\theta=0)=$ incidence angle modifier

$\overline{\mathrm{K}} \quad$ hemispherical average of $K(\theta)$

$\mathrm{K}_{\mathrm{T}} \quad$ clearness index

L latitude (in radians)

m flow rate $(8 / s)$

Q yearly total collectible energy $\left(\mathrm{GJ} / \mathrm{m}^{2}\right)$ per collector aperture area

$\mathrm{T}_{\mathrm{a}}$ ambient temperature

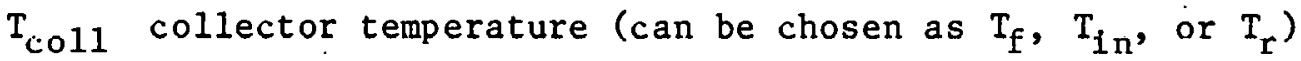

$\mathrm{T}_{\mathrm{f}} \quad\left(\mathrm{T}_{\text {in }}+\mathrm{T}_{\text {out }}\right) / 2$ = mean fluid temperature

$T_{\text {in }}$ fluid inlet temperature

Tout fluid outlet temperature

$\mathrm{T}_{\mathrm{r}}$ receiver surface temperature

$U$ collector heat-loss coefficient or U-value $\left(\mathrm{W} / \mathrm{m}^{2}{ }^{\circ} \mathrm{C}\right)$

$\mathrm{X} \quad \mathrm{U} \Delta \mathrm{T} / \mathrm{n}_{\mathrm{o}}=$ threshold with $\Delta \mathrm{T}=\mathrm{T}_{\mathrm{co} 11}-\mathrm{T}_{\mathrm{a}}$

$\alpha$ absorptance of receiver

$\gamma$ intercept factor 


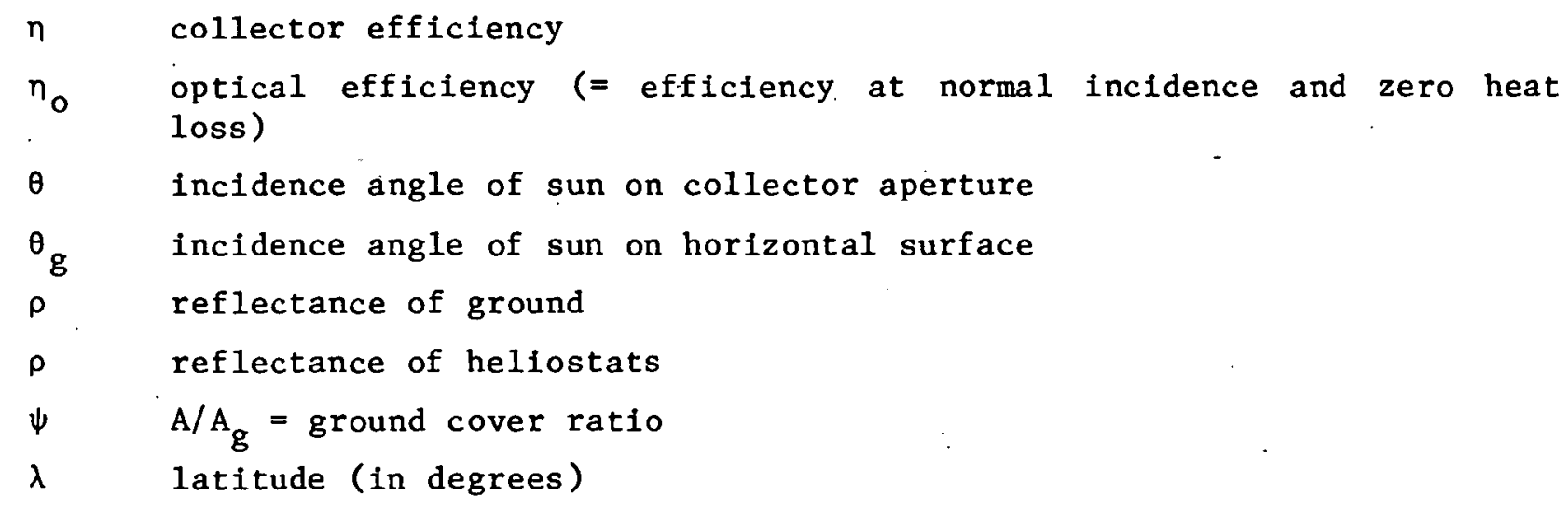




\section{SECTION 1.0}

\section{INTRODUCTION}

Collector tests [1] determine the instantaneous efficiency under standard clear sky conditions. For practical applications, on the other hand, one needs to know the long-term average energy delivered by a real solar energy system, taking into account such effects as variable cloudiness and varying incidence angles. Prediction of system performance can be quite complicated, and frequently a computer simulation is considered necessary [2], requiring considerable expense and expertise. Usually the computing time is too long for a meaningful system optimization [3].

As a simple alternative, shorthand calculational procedures (also called design tools) have been developed. They are suitable for certain standardized solar energy systems, and they are simple enough for programmable hand calculators. Best known among these design tools are the f-chart [4] for active space heating systems and the utilizability method [5] for systems without thermal storage. Recently, these methods have been generalized to a wide class of closed-loop thermal systems [6] and to all collector types $[7,8]$. Since they require monthly calculations, they are still quite tedious-unnecessarily tedious, because for the economic analysis one needs only a single system performance number, namely the yearly total energy delivered by the system.

The present paper develops a set of graphs from which the yearly total energy deliverable by the principal collector types can be read directly. The graphs are derived by fitting simple polynomial expressions of the relevant variables to the results of hour-by-hour computer calculations for all locations in the United States for which hourly insolation measurements are available. The rms deviation between the correlations and the exact results is on the order of $2 \%$ for flat plates and $2 \%$ to $4 \%$ for concentrators. Only three variables are needed: the operating threshold (for thermal collectors this is the average heat loss divided by the optical efficiency), the geographical latitude, and the yearly average direct normal insolation. No other climatic variable is necessary. *

To achieve such a compact presentation of the results, it was, of course, necessary to make certain standardizing assumptions:

- The collector uses all solar radiation above a specified threshold $\mathrm{X}$, and the portion of the solar radiation that is above $X$ is used with constant efficiency.

\footnotetext{
*This remarkable fact can be summed up by the statement: "to a solar collector, all climates look very much alike and differ only in their average direct normal ingolation."
} 
- Transient effects are neglected (this is of little consequence, if the, time constant of the collector field is significantly less than one hour).

- Flat plate and CPC are deployed at tilt equal to latitude.

- Standard spacing between concentrator modules is assumed to account for shading.

- Standard incidence angle modifiers are assumed.

These assumptions are realistic for a wide range of applications [9]. Correction terms could and should be developed in future investigations to account for deviations from the above conditions.

This method can be applied to any system where the collectors operate yearround in such a way that no collected energy is discarded, and, in the case of thermal collectors, where the average threshold is known. This includes

- photovoltaic systems;

- solar-augmented industrial process heat systems; and

- solar thermal power systems.

In addition, the method is recommended for rating collectors of different types or different manufacturers on the basis of yearly average performance. Such a rating provides a buyer of solar collectors with a convenient criterion for selecting the most cost-effective collector. The method is also useful for evaluating the effects of collector degradation, the benefits of collector cleaning [10], and the gains from collector improvements (due to enhanced optical efficiency or decreased heat loss per absorber surface). For most of these applications, the method is accurate enough to replace a system simulation.

Since only the yearly average direct normal irradiance is needed as input, one can use this method for locations where hourly insolation data are not available. A contour map of direct normal irradiance values is included in this paper to permit determination of deliverable energy for any place in the United States. Direct insolation has been monitored only at very few stations in the world, while information for daily total hemispherical irradiation on a horizontal surface is available for a much larger number of locations. To make the present method usable for locations without direct normal insolation data, we have also prepared a correlation between yearly average hemispherical irradiation and direct normal irradiation. 


\section{SECTION 2.0}

\section{ANALYSIS}

\subsection{LESSONS FROM PREVIOUS WORK}

In trying to find simple correlations for seemingly complicated phenomena, the first step is an investigation of functional dependences. One must be sure to identify all variables that have a significant effect, and one wants to neglect all other variables to keep the formalism as simple as possible. For the problem of predicting long-term average collector performance, the utilizability model [7] provided a convenient framework for recognizing functional dependences and general patterns. Like any method for calculating monthly performance of solar energy systems, the utilizability method is complicated by the need to account for seasonal variations in the trigonometric relationships that depend on solar declination. Therefore it was to be expected that correlations for yearly collector output could be far simpler than those for monthly output.

Looking at the formulas of the utilizability method, one finds that the yearly collector output depends on collector type (including tracking mode, incidence angle modifiers, and shading), on threshold (= heat loss/optical efficiency), and on location (latitude and climate). In the utilizability model, the climate enters only through a single variable, the clearness index $\mathrm{K}_{\mathrm{T}}$. The clearness index is defined as the ratio of terrestrial daily total hemispherical irradiation $\mathrm{H}$ and extraterrestrial daily total irradiation $\mathrm{H}_{0}$, both measured on the horizontal surface:

$$
\mathrm{K}_{\mathrm{T}}=\frac{\mathrm{H}}{\mathrm{H}_{\mathrm{O}}}
$$

For monthly performance calculations, one needs the average (over a month of $\mathrm{N}$ days)

$$
\overline{\mathrm{K}}_{\mathrm{T}}=\frac{1}{\mathrm{~N}} \sum_{\mathrm{day}=1}^{\mathrm{N}} \frac{\mathrm{H}}{\mathrm{H}_{\mathrm{o}}}
$$

for each month of the year. The heat loss is based on the monthly average daytime ambient temperature. For the yearly total collectible energy, one is, therefore, lead to expect a close correlation with the yearly average of clearness index and ambient temperature.

In a recent study [11], such correlations were developed by fitting polynomials with constant, linear, and quadratic terms in clearness index, threshold, and latitude to the yearly collectible energy as calculated by the utilizability method [7]. They reproduce the results from the utilizability method within a few percent. 
However, as a fit to a model, the results of Ref. 11 are less credible than a fit to the data themselves could be. 'Therefore, the present paper derives new correlations that are based directly on hour-by-hour simulations with typical meteorological year (TMY) data for the, 26 stations of the SOLMET network [12]. The locations of these stations are shown in Fig. 2-1. Ideally, such collector simulations should employ measured values of beam and of diffuse insolation, but unfortunately such data are rare. Instead, we decided to rely on calculated beam insolation values as they are provided on the SOLMET weather tapes. The algorithm for calculating these beam insolation values was derived by the Aerospace Corporation [13]; it is based on five stations with a total of approximately 12 years of pyrheliometer data. In this regard, we had little choice because we needed data from far more than five stations. We urge, however, that the present model be recalibrated when better data become available.

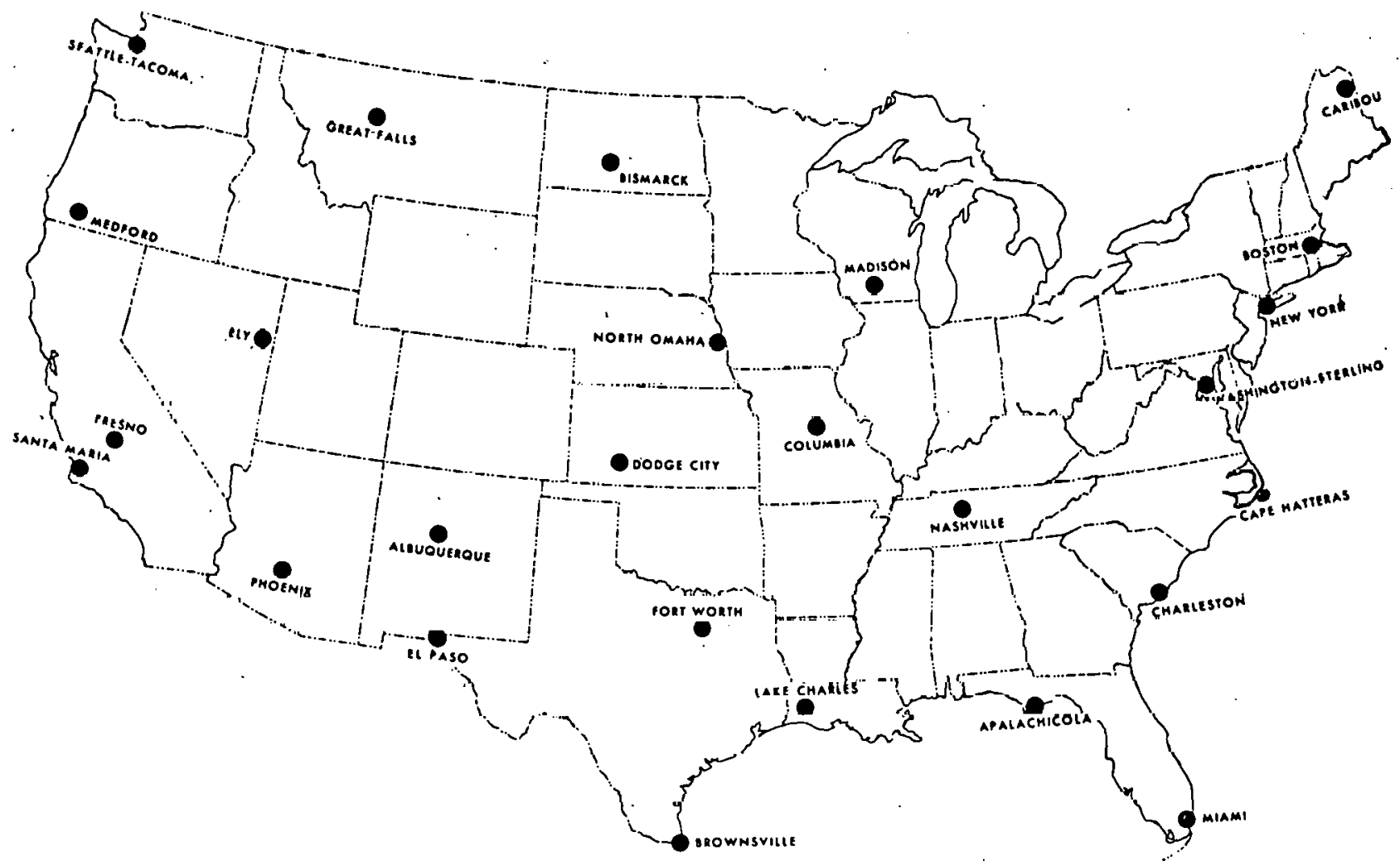

Figure 2-1. The 26 SOLMET Stations 


\subsection{ASSUMPTIONS}

To obtain simple universal relationships for the yearly collectible energy, one must make certain assumptions about the operation of the collectors. Our assumptions are summarized in Table 2-1; they are realistic and typical of a wide range of applications. To avoid misuse, it is imperative that the reader understand these assumptions and be aware of the limitations of this approach.

Table 2-1. ASSUMPTIONS OF THE MODEL

(i) Collector uses all solar radiation above a specified threshold $X$, and the portion of the solar radiation that is above $X$ is used with constant efficiency.

(ii) Hourly time resolution, neglecting transients.

(iii) FLAT PLATE accepts beam and diffuse insolation, and diffuse component is isotropic.

$\mathrm{CPC}$ accepts beam and $\frac{1}{\mathrm{C}}$ diffuse.

Tracking collectors accept only beam insolation.

(iv) No shading for FLAT PLATE and CPC.

For tracking collectors (except TOWER), standard collector spacing with ground cover ratio $\psi=0.5$ for collectors tracking about one axis, and $\psi=$ 0.25 for collectors tracking about two axes.

(v) Incidence angle modifier for FLAT PLATE, CPC, and single-axis trackers:

$$
K(\theta)=1-2.02 \times 10^{-5} \theta^{2}+4.69 \times 10^{-7} \theta^{3}-1.80 \times 10^{-8} \theta^{4},
$$

with $\theta$ in degrees [from Ref. 19].

(vi) For TOWER [31], incidence angle modifier $\mathrm{K}\left(\theta_{\mathrm{g}}, \phi\right)$. (including cosine factors, blocking, shading, atmospheric attenuation, and spillage) is obtained by interpolation of these numbers [from Ref. 16]:

\begin{tabular}{|c|c|c|c|c|c|c|c|}
\hline \multirow{2}{*}{$\begin{array}{c}\text { Zenith angle } \theta \mathrm{g} \\
\text { [degrees; horizon }=90^{\circ} \text { ] }\end{array}$} & \multicolumn{7}{|c|}{ Azimuth $\phi[$ degrees; south $=0]$} \\
\hline & 0 & 30 & 60 & 75 & 90 & 110 & 130 \\
\hline 0.5 & 0.759 & 0.759 & 0.762 & 0.747 & 0.758 & 0.763 & 0.757 \\
\hline 25 & 0.760 & 0.744 & 0.746 & 0.742 & 0.733 & 0.728 & 0.712 \\
\hline 45 & 0.799 & 0.711 & 0.696 & 0.687 & 0.672 & 0.660 & 0.666 \\
\hline 65 & 0.622 & 0.620 & 0.597 & 0.580 & 0.573 & 0.553 & 0.546 \\
\hline 75 & 0.496 & 0.498 & 0.472 & 0.470 & 0.450 & 0.436 & 0.428 \\
\hline 85 & 0.240 & 0.239 & 0.229 & 0.227 & 0.221 & 0.216 & 0.213 \\
\hline
\end{tabular}


Prior to discussing the assumptions, we list the seven collector types considered in this paper:

- FLAT PLATE. Planar collector with fixed tilt equal to latitude, facing due south. (For evacuated tubular collectors, see the Appendix.)

- CPC. Compound parabolic concentrator $[14,15]$ with geometric concentration ratio $C=1.5$, acceptance half-angle $35^{\circ}$, with fixed tilt equal to latitude, and facing due south.

- EAST WEST. Collector with aperture tracking about horizontal east-west axis.

- NORTH SOUTH. Collector with aperture tracking about horizontal northsouth axis.

- POLAR, Collector with aperture trarking ahnut pnlar, axis, i:e., about north-oouth axis with tilt equal tu latilude.

- TWO-AXIS. Collector with two-axis tracking whose aperture is always normal to the sun (e.g., parabolic dish and point-focus Fresnel lens).

- TOWER. Power tower or central receiver of a design characterized by the optical efficiency-incidence angle relationship in Table 2-1 [16,31].

Now let us describe the computer calculation in detail. For each hour of the year, the beam irradiance $I_{b}$ (at normal incidence) and the hemispherical irradiance $I_{h}$ (on horizontal surface) are read from the SOLMET weather tapes. The insolation values are interpreted as constant values during that hour, and all incidence angles are calculated for the midpoint of earh hnur.*

The diffuse irradiance

$$
I_{d}=I_{h}-I_{b} \cos \theta_{g},
$$

with $\theta_{g}=$ incidence angle on the ground, is assumed to be isotropic. This assumption is made necessary by the lack of more detailed data; it affects only the FLAT PLATE and to a lesser degree the CPC, leading to underprediction of, at most, a few percent [17].

The irradiance $I_{\text {coll }}$ incident on the collector aperture is calculated by including the appropriate incidence angle modifier $K(\theta)$ for the optical efficiency. $n_{0}$ is the optical efficiency at normal incidence, and $n_{0} K(\theta)$ is the optical efficiency when the incidence angle is $\theta$. Incidence-anglemodifier data can be found in Ref. 1 for flat-plate collectors, in Ref. 18 for nonevacuated CPCs, and in Ref. 19 for parabolic troughs.

* If sunrise or sunset occur during the hour, the insolation is taken to be incident during the period after sunrise or before sunset. Since planar photovoltaic panels can operate on diffuse radiation alone, we have included for the flat-plate case the contribution of diffuse radiation before $6 \mathrm{a} . \mathrm{m}$. and after $6 \mathrm{p} . \mathrm{m}$. during summer when no direct insolation is incident on the front of the panel. 
Since incidence angle modifiers vary as much between collectors of the same generic type as between different collector types, it appears reasonable to select one typical modifier and use it for all collector types other than the power tower. For this purpose, the incidence angle modifier of the SERI Hexcel collector in Ref. 19 is a good compromise; it is

$$
K(\theta)=1-2.02 \times 10^{-5} \theta^{2}+4.69 \times 10^{-7} \theta^{3}-1.80 \times 10^{-8} \theta^{4}
$$

with $\theta$ in degrees. The average of $K(\theta)$ for isotropic radiation is

$$
\overline{\mathrm{K}}=2 \int_{0}^{\pi / 2} \mathrm{~d} \theta \sin \theta \cos \theta \mathrm{K}(\theta)
$$

The optical efficiency $\eta_{0}$ is left out of the simulation and applied as a multiplicative factor to the end result.

Thus the irradiance $\mathrm{I}_{\mathrm{co} 11}$ on the FLAT PLATE is

$$
\begin{aligned}
\mathrm{I}_{\text {flat plate }}= & \mathrm{I}_{\mathrm{b}} \mathrm{K}(\theta) \operatorname{Max}[\cos \theta, 0] \\
& +\frac{\overline{\mathrm{K}}}{2}\left[\mathrm{I}_{\mathrm{d}}(1+\cos \lambda)+\rho \mathrm{I}_{\mathrm{h}}(1-\cos \lambda)\right],
\end{aligned}
$$

where

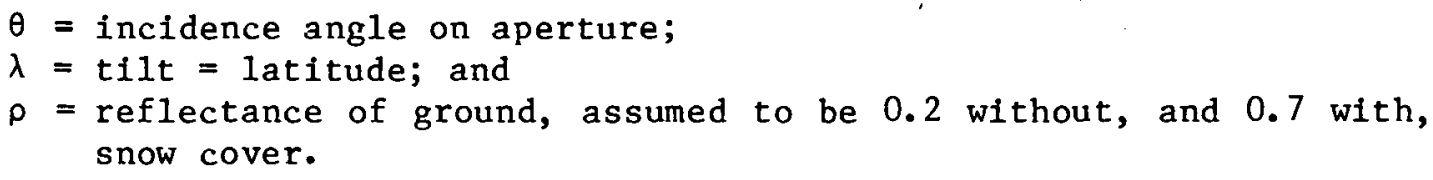
snow cover.

For a CPC with geometric concentration ratio $C$, the irradiance on the aperture is taken as

$$
I_{C P C}=I_{b} K(\theta) \cos \theta+\frac{\bar{K}}{C} I_{d}
$$

when the beam component is within the acceptance angle, and zero when it is outside.

Further details can be found in Ref. 8, in particular the equations for $\theta$ as a function of collector type and time of day and the formulas for the CPC cutoff time. The tracking collectors are assumed to accept only the beam component of the insolation. 
In most installations, several collector modules will be connected to each other, and hence they may shade each other during some periods. Since shading is installation-dependent, we have made certain assumptions about the deployment of collector modules. For flat plates, we have neglected shading altogether, since flat plates are frequently installed on roofs of houses where they do not interfere with each other. For CPCs we have also neglected shading because the limited acceptance angle rules out shading during operating hours, at least for reasonable collector spacing at low and intermediate latitudes [15].

For collectors with single-axis tracking, the analysis of shading is straightforward if, as will usually be the case, the collector rows are long enough to permit neglect of end effects. Let $\psi$ be the ground cover ratio, i.e., the ratio

$$
\psi=\frac{\mathrm{A}}{\mathrm{A}_{\mathrm{g}}}
$$

of the aperture area $A$ of the collector array and of the ground area $A_{g}$ that is taken up by the collector array. When the collector rows do not shade each other, the beam irradiance on the collector array is

$$
\mathrm{A} \mathrm{I}_{\mathrm{b}} \cos \theta \cdot \mathrm{K}(\theta) \text {. }
$$

Whenever there is shading, no beam insolation reaches the ground, and hence the irradiance available to the collector array is

$$
A_{g} I_{b} \cos \theta_{g} K(\theta)
$$

where $\theta_{\mathrm{g}}$ is the incidence angle of the sun on the horizontal surface. Hence the irrădiance per aperture area of single-axis tracking collectors is

$$
I_{1-\text { axis }}=I_{b} K(\theta) \operatorname{Min}\left[\cos \theta, \frac{\operatorname{sins} \theta_{g}}{\psi}\right] \text {. }
$$

For arrays of coliectors with polar tracking axis, this formula is correct if $\psi$ is defined in the plane of the tracking axis. We assume this to be the case, since such collectors are likely to find their main application in relatively small installations with a single plane of collector modules, e.g., on a tilted roof. For simplicity, we have used Eq. 2-9a even for the TWO-AXIS case, where it provides an upper bound rather than the exact result for the available insolation. We have taken a ground cover ratio

$$
\psi=0.5
$$


as a typical value for all collectors with one-axis tracking. For the TWOAXIS case we assumed the value*

$$
\psi=0.25 \text {. }
$$

For the central receiver, the incidence angle modifier depends on zenith and azimuth angles and is obtained by interpolating the numbers in Table 2-1. For consistency with the numbers in Table 2-1, the aperture area of the central receiver is defined as the surface area of the heliostats. Shading and blocking effects are included in the incidence angle modifier $\mathrm{k}\left(\theta_{g}, \phi\right)$ of Table $2-1$, and the irradiance per aperture area (= heliostat area) is

$$
I_{\text {central }} \text { receiver }=I_{b} \mathrm{~K}\left(\theta_{g}, \phi\right) \text {. }
$$

To account for heat losses, a threshold $X$ is defined as ratio of heat loss and optical efficiency. A range of threshold values, $\mathrm{X}=0,0.1,0.2$. . 0.9 , $1.0 \mathrm{~kW} / \mathrm{m}^{2}$, is considered, and for each value of $X$ the collectible insolation $\left(I_{c o l l}-X\right)$ is summed to obtain the yearly total

$$
Q_{\text {data }}(X)=\sum_{\text {year }}\left[I_{\operatorname{col} 11}-X\right]_{+}
$$

for each of the seven collector types, the + subscript under the bracket indicating that only positive summands are included.

This formulation does not accommodate transients of the collector field. The collector pump is turned on whenever the irradiance $I_{\text {coll }}$ on the aperture is above the threshold; otherwise it is turned off. This assumption is good for small collector arrays at low temperature, since the warm-up time of a we11designed collector module is much shorter than one hour. For large collector arrays, the transit time of a fluid element through the collector array may be long enough to make the time constant of the collector array significantly longer than that of an individual module. In that case, or in the case of high-temperature operation, the warm-up time may be long enough to require correction terms for Eq. 2-11.

* Because of the different ground cover ratios, the ratio of radiation availability for TWO-AXIS and for POLAR differs from the yearly average, 0.96, of the cosine of the solar declination [7]. 


\subsection{RESULTS}

Having calculated the yearly collectible energy $Q_{\text {data }}(X)$ as a function of threshold $X$ for each of the 26 SOLMET stations, we fitted the results with polynomials in threshold, latitude, and average beam irradiance. To avoid coefficients that are very large or very small, we chose the following units:

- The collectible energy $Q$ is given in $\mathrm{GJ} / \mathrm{m}^{2}$.

- The threshold $\mathrm{X}$ is given in $\mathrm{kW} / \mathrm{m}^{2}$.

- The latitude $\mathrm{L}$ is given in radians.

- The yearly average direct normal irradiance during daylight hours I is given in $\mathrm{kW} / \mathrm{m}^{2}$.

Let us illustrate the fitting procedure for the EAST-WEST, POLAR, and TWO-AXIS cases, because these tracking motions maintain the same orientation between collector and sun, regardless of latitude. Furthermore, seasonal differences in length of day cancel exactly between summer and winter. Hence the yearly collectible energy for these tracking modes is independent of latitude if shading and atmospheric absorption are neglected; in practice, latitude independence is an excellent approximation for ground cover ratios $\psi \leqslant 0.5$ and for latitudes between $25^{\circ}$ and $45^{\circ}$. For these collector types, we have fit $Q_{\text {data }}(X)$ with polynomials of the form:

$$
Q=a_{1}+a_{2} I+a_{3} I^{2}+\left(a_{4}+a_{5} I+a_{6} I^{2}\right) X+\left(a_{7}+a_{8} I+a_{9} I^{2}\right) X^{2}
$$

Our criterion for the best fit is the minimization of the sum of squared differences between data and fit

$$
x^{2}=\sum_{\text {stations }} \sum_{x}\left\{Q_{\text {data }}-Q\right\}^{2},
$$

the sum running over all 26 stations and over the threshold values $X=0,0.1$, $0.2,0.3,0.4,0.5$, and $0.6 \mathrm{~kW} / \mathrm{m}^{2}$. This requires the solution of a system of nine linear equations corresponding to

$$
\frac{\partial x^{2}}{\partial a_{i}}=0, \quad 1=1, \ldots 9,
$$

with nine unknowns $a_{i}$. For the other collector types, latitude dependence cannot be neglected, and we have used a fit of the form 


$$
\begin{aligned}
Q= & a_{1}+a_{2} I+\left(a_{3}+a_{4} I\right) L+\left(a_{5}+a_{6} I\right) L^{2} \\
& +\left[a_{7}+a_{8} I+\left(a_{9}+a_{10} I\right) L+\left(a_{11}+a_{12} I\right) L^{2}\right] x \\
& +\left[a_{13}+a_{14} I+\left(a_{15}+a_{16} I\right) L+\left(a_{17}+a_{18} I\right) L^{2}\right] x^{2},
\end{aligned}
$$

where $L$ is the latitude in radians. The fits are plotted versus $X$ in Figs. 2-2 to 2-8, and the coefficients are listed below each figure.

We have not included latitude dependence for the central receiver since incidence angle modifiers for latitudes other than $35^{\circ}$ have not been published. Hence we have used only data for locations between $33^{\circ}$ and $37^{\circ}$, and have fitted the results with a polynomial that is linear in $I$ and quadratic in $x$. However, it is likely that a central receiver that is optimized for a different latitude will yield roughly the same energy per heliostat area [32].

Having derived such curve fits, one would like to determine how much discrepancy is to be expected between the fits and the exact answer (the latter being defined as the result of the hour-by-hour computer calculation). Two measures of the discrepancy are of interest: the mean error or bias, and the rms error or standard deviation. We have calculated bias and standard deviation for each value of the threshold $X$, averaged over the 26 stations, The results are listed in Tables 2-2 to $2-7$, both as absolute error (in $\mathrm{GJ} / \mathrm{m}^{2}$ ) and as relative error (in \%). The bias is defined as

$$
\bar{\delta}=\frac{1}{26} \sum_{\text {stations }}\left(Q_{\text {data }}-Q\right)
$$

in absolute units, and as

$$
\bar{\varepsilon}=\frac{1}{26} \sum_{\text {stations }}\left(Q_{\text {data }}-Q\right) / Q
$$

in relative units. The absolute and relative rms errors are defined as

and

$$
\delta_{\mathrm{rms}}=\left[\frac{1}{26} \sum_{\text {stations }}\left(Q_{\mathrm{data}}-Q\right)^{2}\right]^{1 / 2}
$$

$$
\varepsilon_{\mathrm{rms}}=\left[\frac{1}{26} \sum_{\text {stations }}\left[\left(Q_{\text {data }}-Q\right) / Q\right]^{2}\right] 1 / 2 .
$$


Table 2-2. VALIDATION OF MODEL FOR FLAT-PLATE COLLECTOR

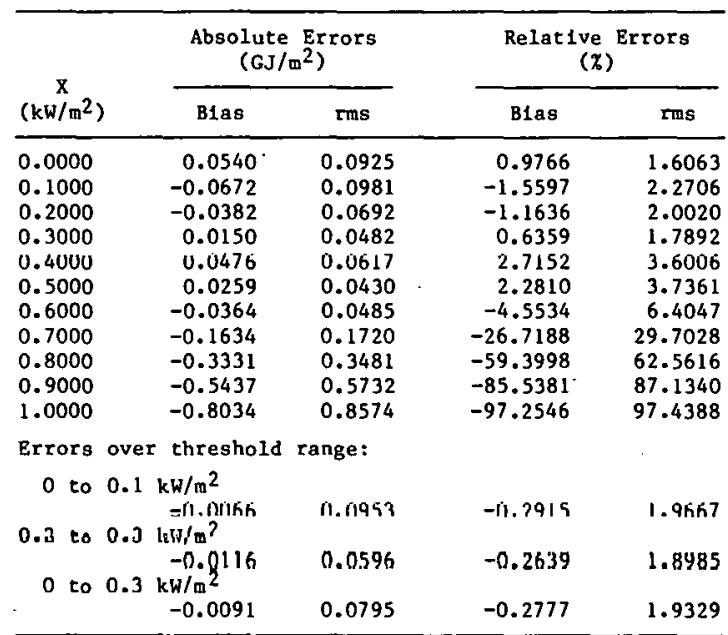

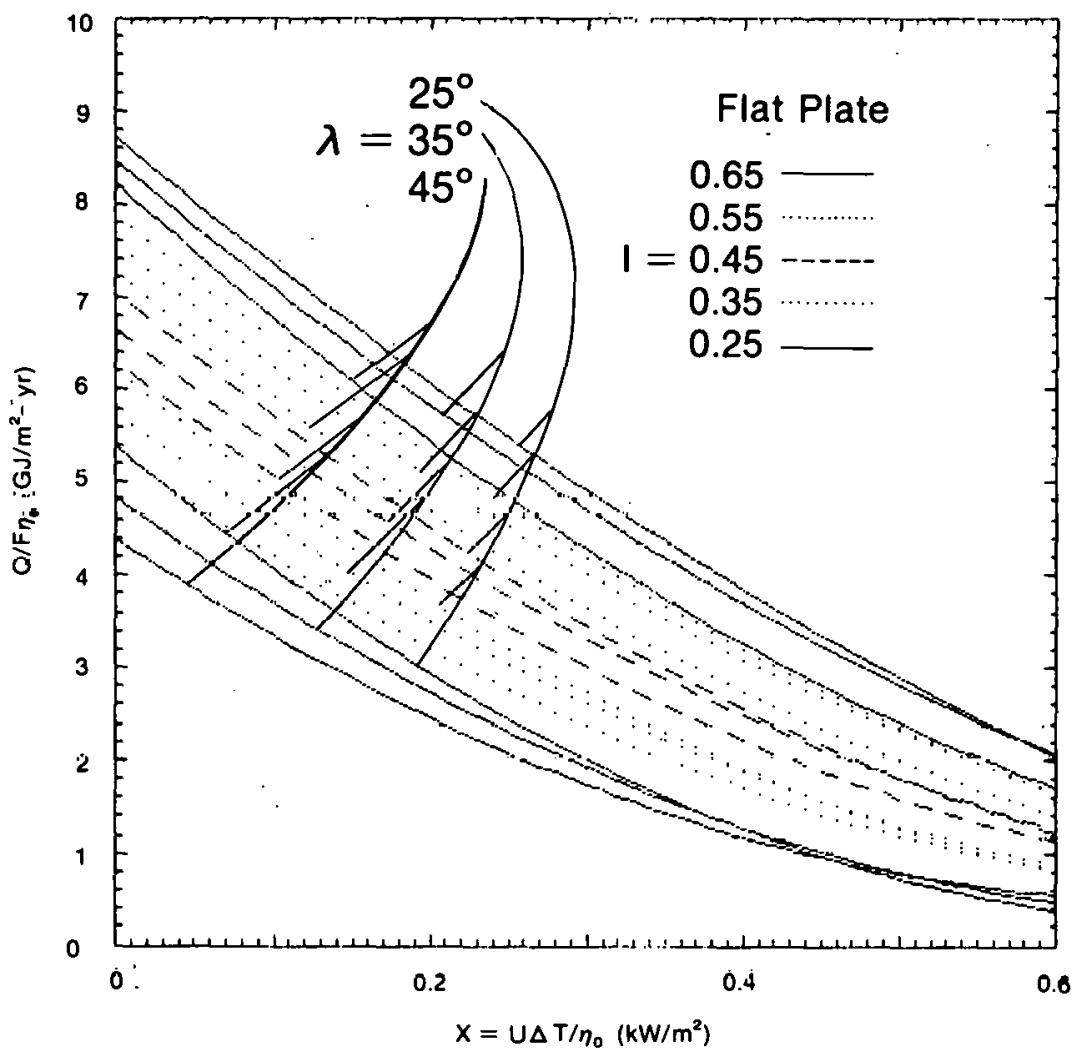

$$
\begin{aligned}
\mathrm{Q} /(\mathrm{Fn} \mathrm{O})= & (6.112+5.027 \mathrm{I})+(-7.888+9.691 \mathrm{I}) \mathrm{L}+(3.370-4.935 \mathrm{I}) \mathrm{L}^{2} \\
& +\left[(-29.692+18.517 \mathrm{I})+(46.256-49.819 \mathrm{I}) \mathrm{L}+(-24.881+16.352 \mathrm{I}) \mathrm{L}^{2}\right] \mathrm{X} \\
& +\left[(32.415-43.300 \mathrm{I})+(-63.282+97.141 \mathrm{I}) \mathrm{L}+\left(41.811-55.270 \mathrm{~T}_{1}\right) \mathrm{L}^{2}\right] \mathrm{X}^{2}
\end{aligned}
$$

Figure 2-2: Yearly Collectible Energy $Q$ for Flat Plate, Shown as Graph and as Curve Fit for $Q /\left(F_{\eta 0}\right)$, as Function of Threshold $X$ (in $\mathrm{kW} / \mathrm{m}^{2}$ ), of Direct Normal Irradiance I (in $\mathrm{kW} / \mathrm{m}^{2}$ ), and of Latitude ( $A$ in Degrees, $L$ in Radians). 
Table 2-3. VALIDATION OF MODEL FOR CPC.

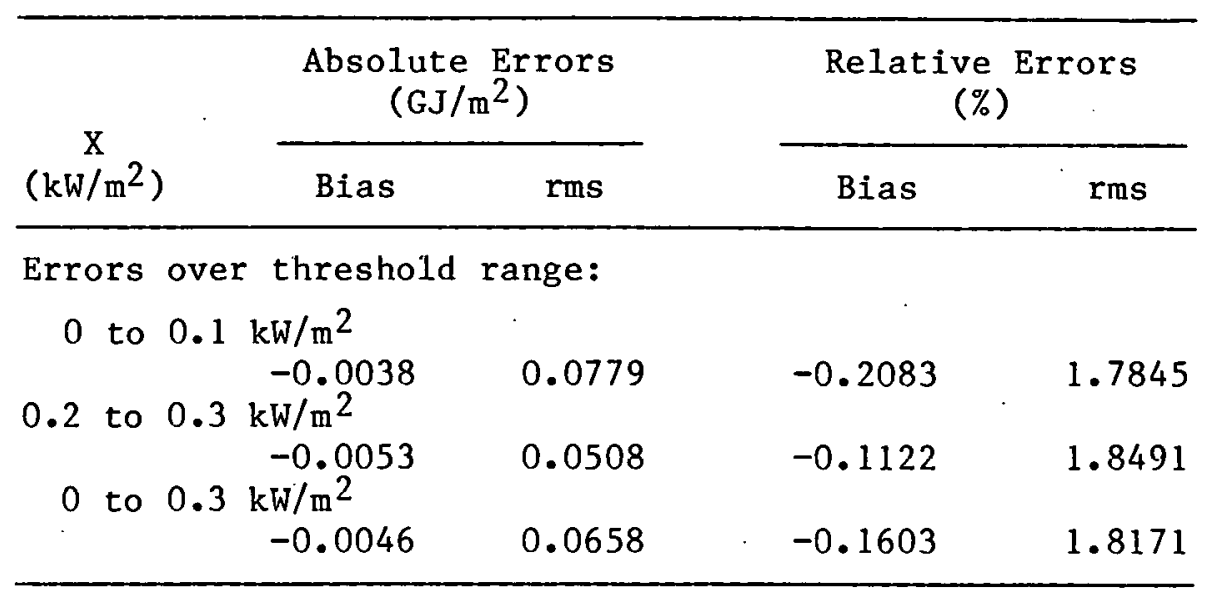

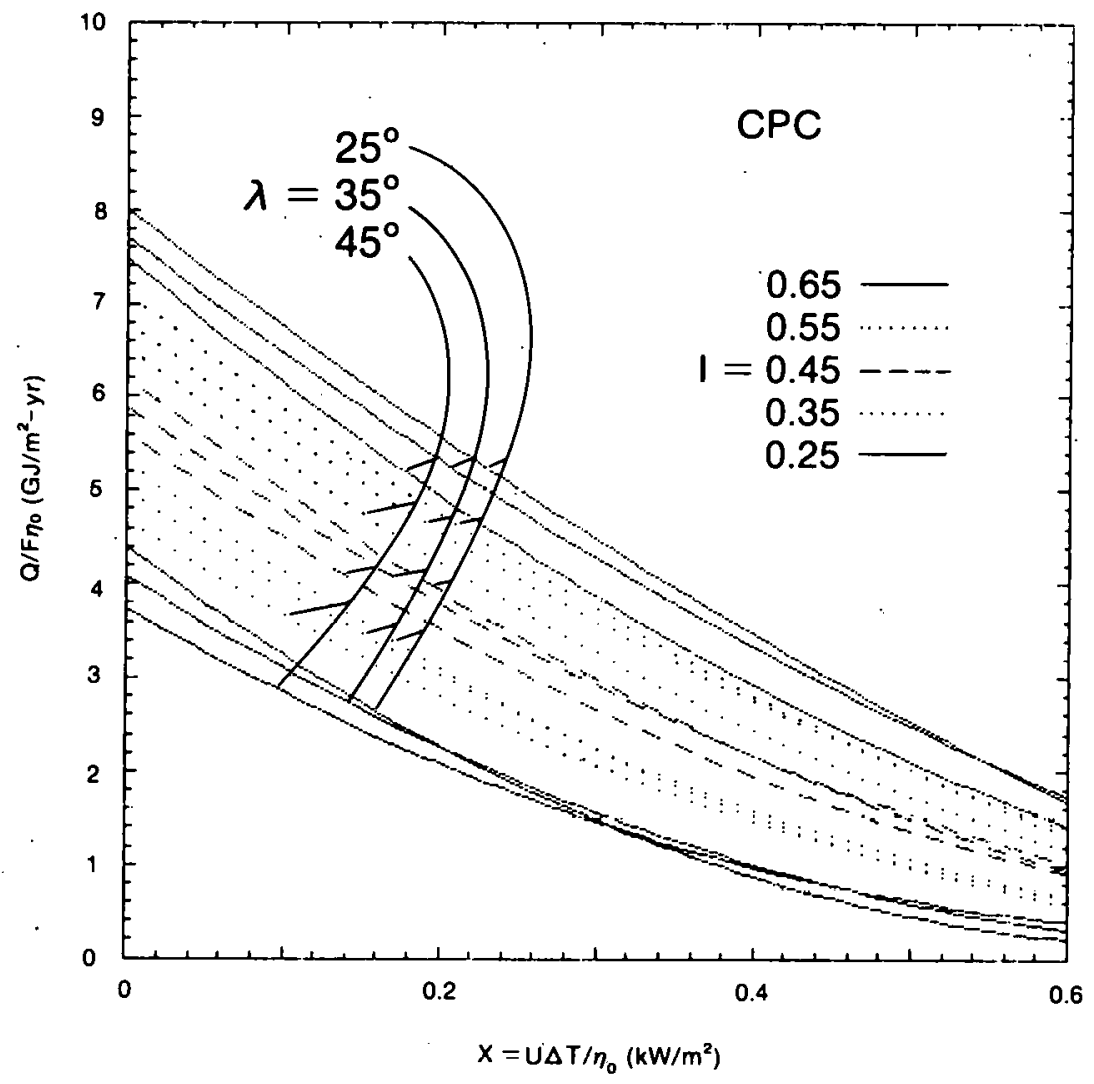

$$
\begin{aligned}
\mathrm{Q} /\left(\mathrm{F} \mathrm{n}_{\mathrm{O}}\right)= & (2.497+10.107 \mathrm{I})+(-0.115-4.407 \mathrm{I}) \mathrm{L}+(-1.642+4.392 \mathrm{I}) \mathrm{L}^{2} \\
& +\left[(-23.714+8.286 \mathrm{I})+(33.106-18.932 \mathrm{I}) \mathrm{L}+(-14.786-7.181 \mathrm{I}) \mathrm{L}^{2}\right] \mathrm{X} \\
& +\left[(32.271-41.761 \mathrm{I})+(-62.773+84.556 \mathrm{I}) \mathrm{L}+\left(38.703-40.804 \mathrm{I}^{2}\right] \mathrm{X}^{2}\right.
\end{aligned}
$$

Figure 2-3. Yearly Collectible Energy $Q$ for CPC, Shown as Graph and as Curve Fit for $Q /\left(F \eta_{0}\right)$, as Function of Threshold $X$ (in $k W / m^{2}$ ), of Direct Normal Irradiance I (in $\mathrm{kW} / \mathrm{m}^{2}$ ), and of Latitude ( $\lambda$ in Degrees, $L$ in Radians) 
Table 2-4. VALIDATION OF MODEL FOR CONCENTRATOR WITH EAST-WEST TRACKING AXIS

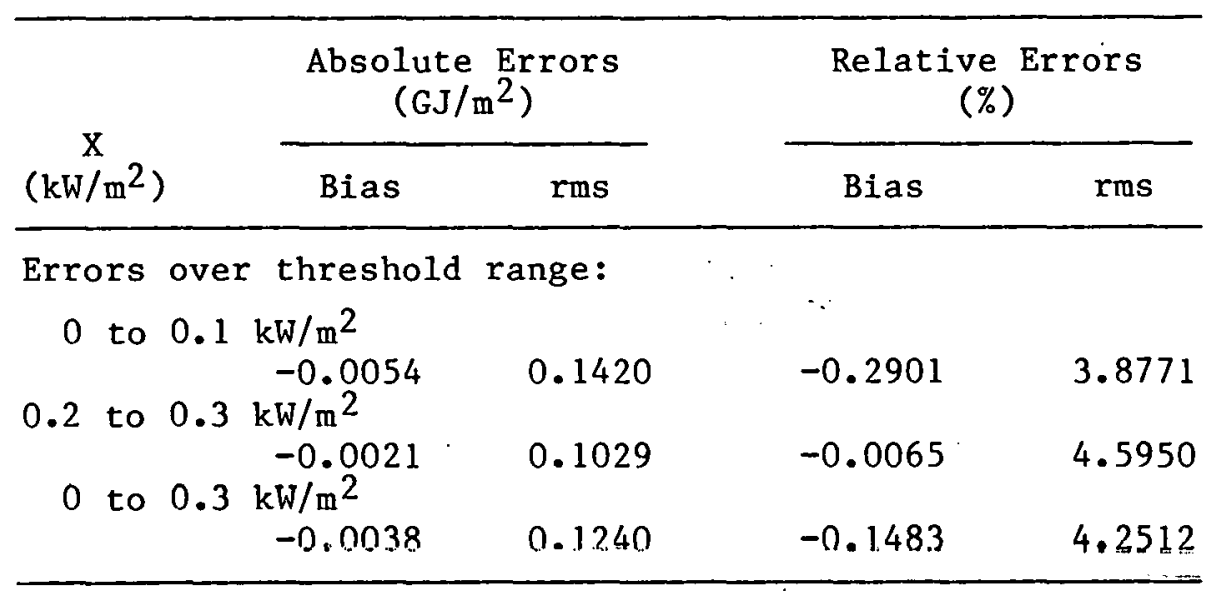

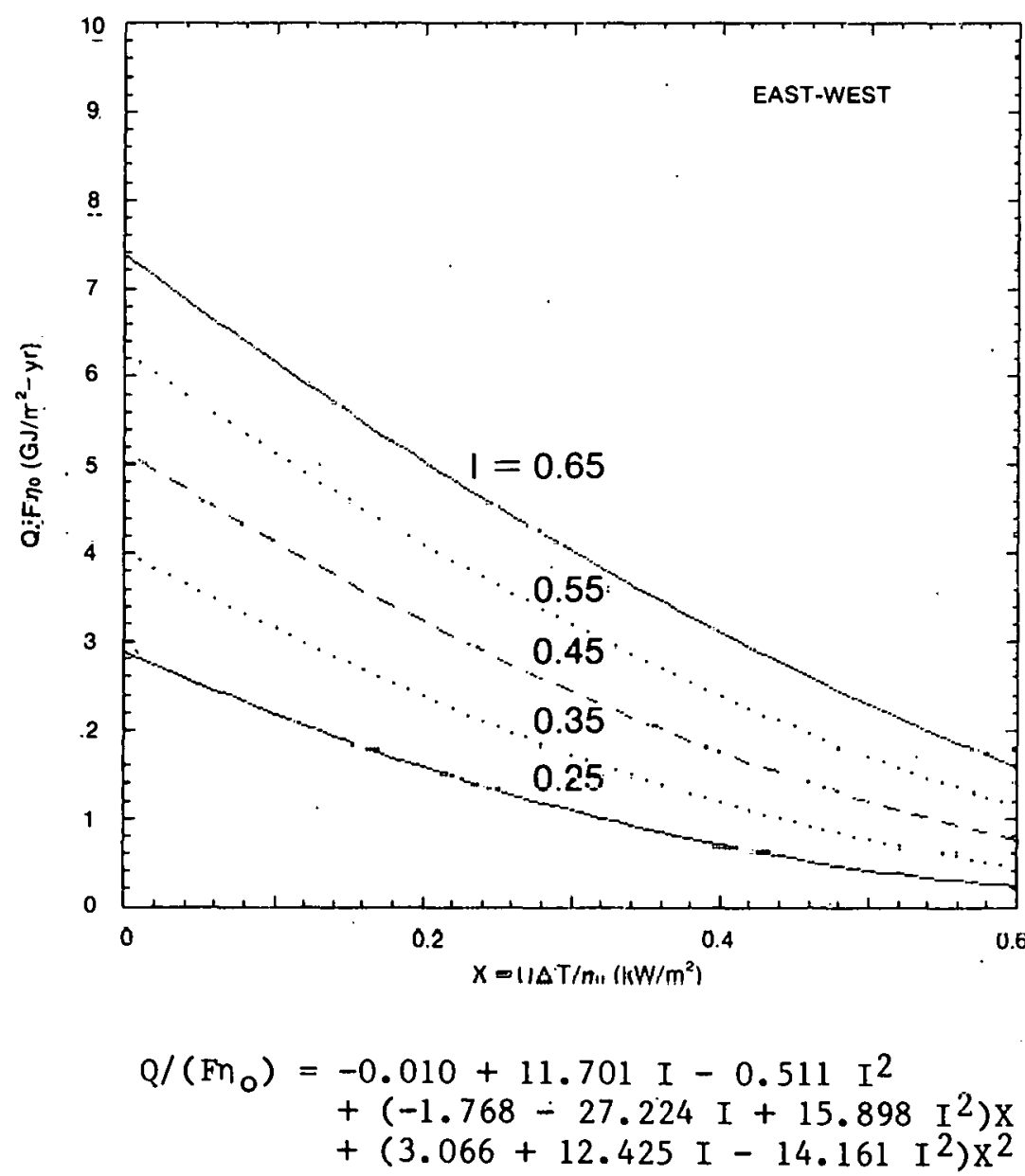

Figure 2-4. Yearly Collectible Energy $Q$ for Concentrator Tracking about EAST-WEST Axis, Shown as Graph and as Curve Fit for $Q /\left(F n_{0}\right)$, as Function of Threshold $X$ (in $\mathrm{kW} / \mathrm{m}^{2}$ ), and of Direct Normal Irradiance!l (in $\mathrm{kW} / \mathrm{m}^{2}$ ). 
Table 2-5. VALIDATION OF MODEL FOR CONCENTRATOR WITH HORIZONTAL NORTH-SOUTH TRACKING AXIS

\begin{tabular}{|c|c|c|c|c|}
\hline \multirow{2}{*}{$\underset{\left(\mathrm{kw} / \mathrm{m}^{2}\right)}{\mathrm{X}}$} & \multicolumn{2}{|c|}{$\begin{array}{c}\text { Absolute Errors } \\
\left(\mathrm{GJ} / \mathrm{m}^{2}\right)\end{array}$} & \multicolumn{2}{|c|}{$\begin{array}{c}\text { Relative Eerors } \\
(x)\end{array}$} \\
\hline & Blas & $\mathrm{rms}$ & B1as & $\mathrm{rms}$ \\
\hline $\begin{array}{l}0.0000 \\
0.1000 \\
0.2000 \\
0.3000 \\
0.4000 \\
0.5000 \\
0.6000 \\
0.7000 \\
0.8000 \\
0.9000 \\
1.0000\end{array}$ & $\begin{array}{r}0.0183 \\
-0.0288 \\
-0.0047 \\
0.0109 \\
0.0100 \\
0.0011 \\
-0.0062 \\
-0.0083 \\
-0.0037 \\
-0.0083 \\
-0.0819\end{array}$ & $\begin{array}{l}0.1013 \\
0.1043 \\
0.0974 \\
0.0913 \\
0.0828 \\
0.0701 \\
0.0563 \\
0.0685 \\
0.1274 \\
0.2479 \\
0.4376\end{array}$ & $\begin{array}{r}0.4454 \\
-0.9465 \\
-0.3010 \\
0.5607 \\
1.0949 \\
0.9344 \\
-0.3702 \\
9.7759 \\
48.0248 \\
8.8012 \\
3.4230\end{array}$ & $\begin{array}{r}2.1874 \\
3.0505 \\
3.8331 \\
5.0303 \\
6.8580 \\
9.6179 \\
16.7132 \\
91.1281 \\
260.7966 \\
252.3109 \\
252.9788\end{array}$ \\
\hline $\begin{array}{rll}\text { Errors ove } & \\
0 & \text { to } & 0.1 \\
0.2 & \text { to } & 0.3 \\
0 & \text { to } & 0.3\end{array}$ & $\begin{array}{l}\text { threshol } \\
\mathrm{kW} / \mathrm{m}^{2} \\
-0.0053 \\
\mathrm{~kW} / \mathrm{m}^{2} \\
0.0031 \\
\mathrm{kH} / \mathrm{m}^{2} \\
-0.0011\end{array}$ & $\begin{array}{l}0.1028 \\
0.0944\end{array}$ & -0.2506 & 2.6543 \\
\hline
\end{tabular}

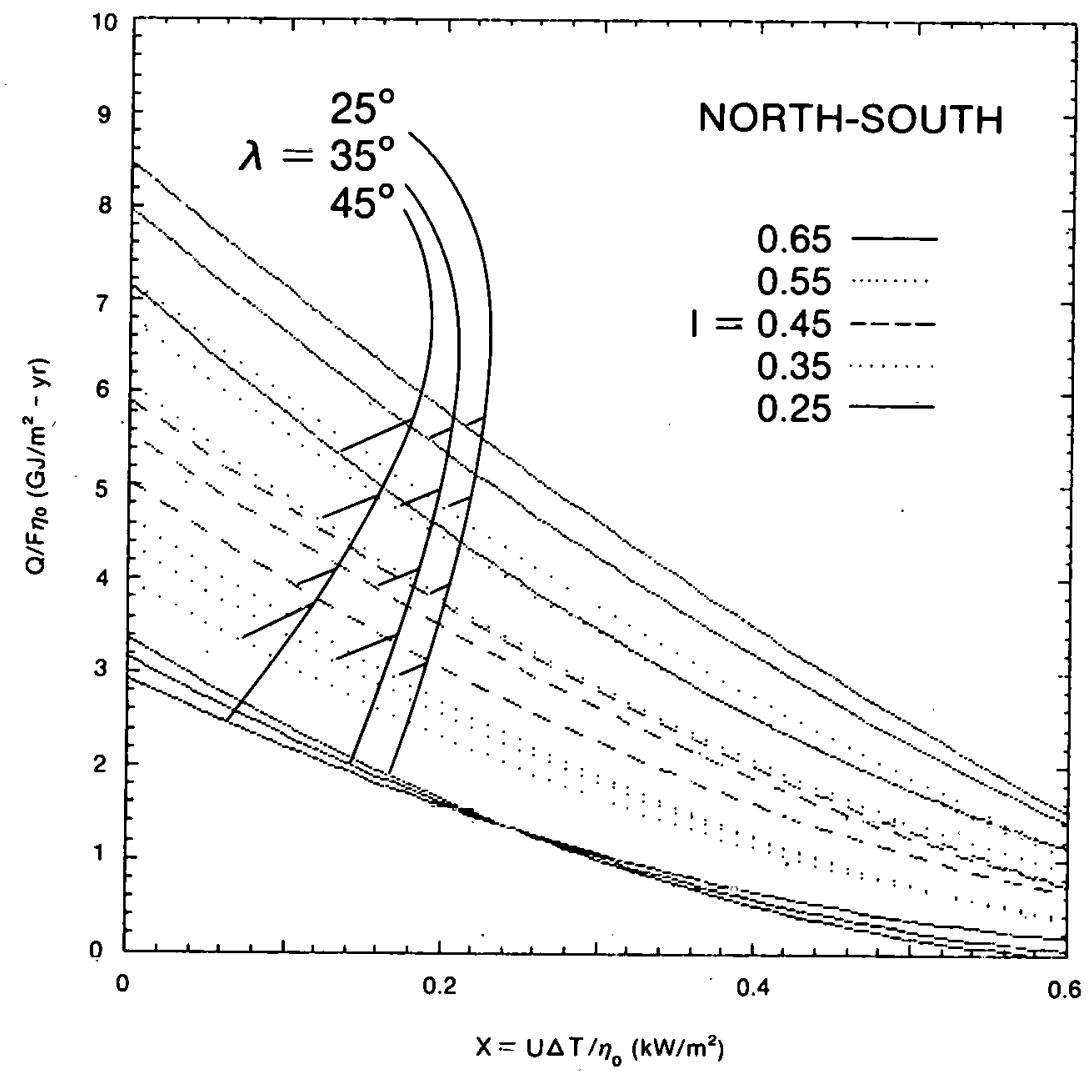

$$
\begin{aligned}
& \mathrm{Q} /\left(\mathrm{F \eta _{ \textrm {O } }}\right)=(0.917+11.453 \mathrm{I})+(-2.769+8.094 \mathrm{I}) \mathrm{L}+(2.507-11.763 \mathrm{I}) \mathrm{L}^{2} \\
& +\left[(-9.480-12.976 \mathrm{I})+(0.194+21.747 \mathrm{I}) \mathrm{L}+(9.298-34.109 \mathrm{I}) \mathrm{L}^{2}\right] \mathrm{X} \\
& +\left[(11.954-3.755 \mathrm{I})+(-0.225-37.385 \mathrm{I}) \mathrm{L}+(-12.584+62.705 \mathrm{I}) \mathrm{L}^{2}\right] \mathrm{X}
\end{aligned}
$$

Figure 2-5. Yearly Collectible Energy $Q$ for Concentrator Tracklng about Horizontal NORTH-SOUTH Axis, Shown as Graph and as Curve Fit for $Q /\left(F_{\eta_{0}}\right)$ as Function of Threshold $X$ (in $\left.\mathrm{kW} / \mathrm{m}^{2}\right)$, of Direct Normal Irradiance I (in $\mathrm{kW} / \mathrm{m}^{2}$ ), and of Latitude [ $\boldsymbol{A}$ in Degrees, $L$ in Radians] 
Table 2-6. VALIDATION OF MODEL FOR CONCENTRATOR WITH POLAR TRACKING AXIS

\begin{tabular}{|c|c|c|c|c|}
\hline \multirow{2}{*}{$\frac{\mathrm{X}}{\left(\mathrm{kW} / \mathrm{m}^{2}\right)}$} & \multicolumn{2}{|c|}{$\begin{array}{l}\text { Absolute Errors } \\
\left(\mathrm{GJ} / \mathrm{m}^{2}\right)\end{array}$} & \multicolumn{2}{|c|}{$\underset{(\%)}{\text { Relative Errors }}$} \\
\hline & Bias & rms & Bias & rms \\
\hline \multicolumn{5}{|c|}{$\begin{array}{l}\text { Errors over threshold range: } \\
0 \text { to } 0.1 \mathrm{~kW} / \mathrm{m}^{2}\end{array}$} \\
\hline \multirow{3}{*}{$\begin{array}{r}0.2 \text { to } 0.3 \\
0 \text { to } 0.3\end{array}$} & $0.3 \mathrm{~kW} / \mathrm{m}^{2}$ & 0.0835 & -0.2144 & 1.9045 \\
\hline & $0.3 \mathrm{~kW} / \mathrm{m}^{2}$ & 0.0617 & 0.1475 & 2.3354 \\
\hline & -0.0017 & 0.0734 & -0.0334 & 2.1309 \\
\hline
\end{tabular}

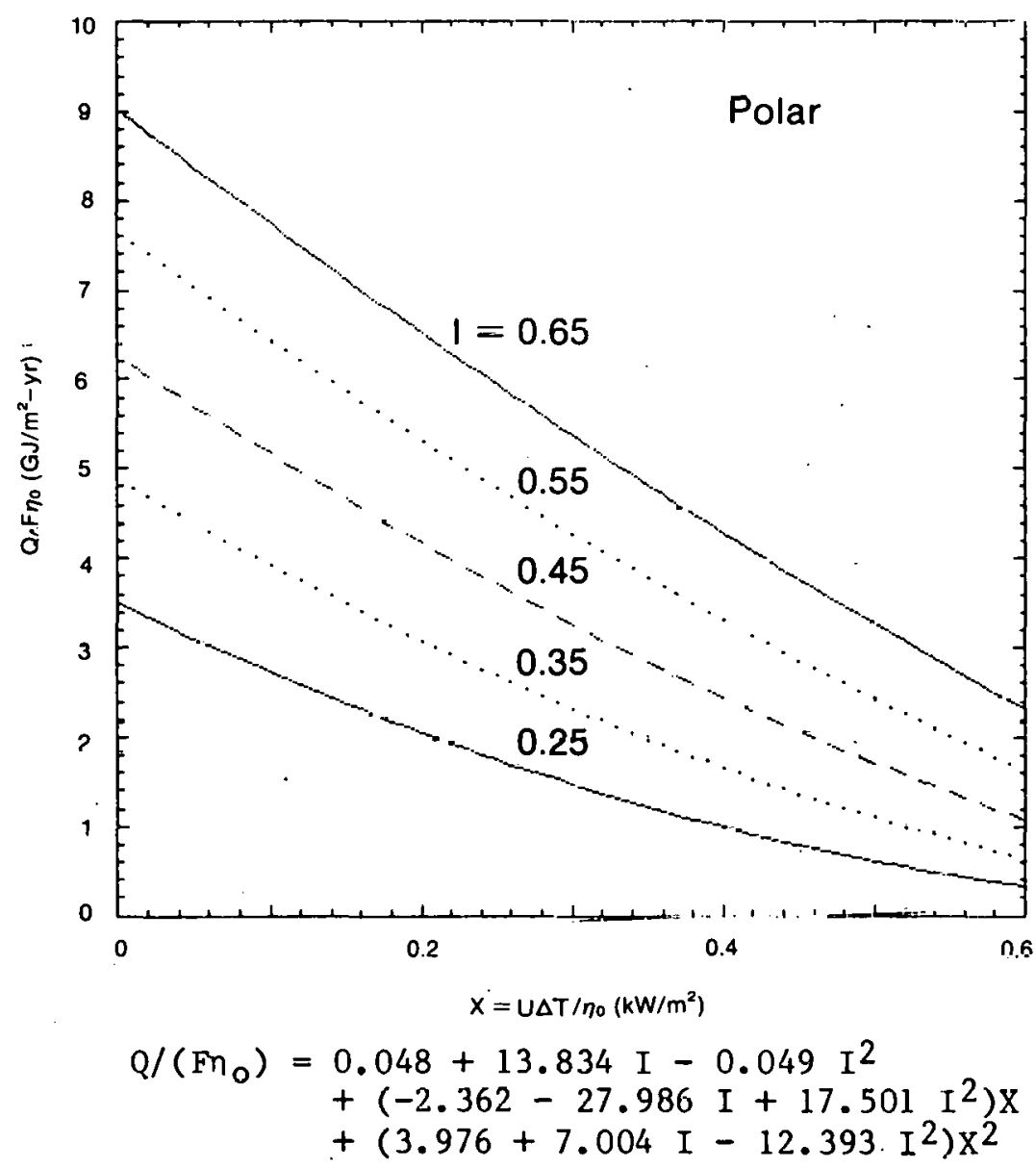

Figure 2-6. Yearly Collectible Energy $Q$ for Concentrator Tracking about POLAR Axis, Shown as Graph and as Curve Fit for $Q /\left(F_{g_{1}}\right)$, as Function of Threshold $X$ (in $\mathrm{kW} / \mathrm{m}^{2}$ ), and of Direct Normal Irradiance I (in $\mathbf{k W} / \mathrm{m}^{2}$ ). 
Table 2-7. VALIDATION OF MODEL FOR CONCENTKATOR WITH TWO-AXIS TRACKING

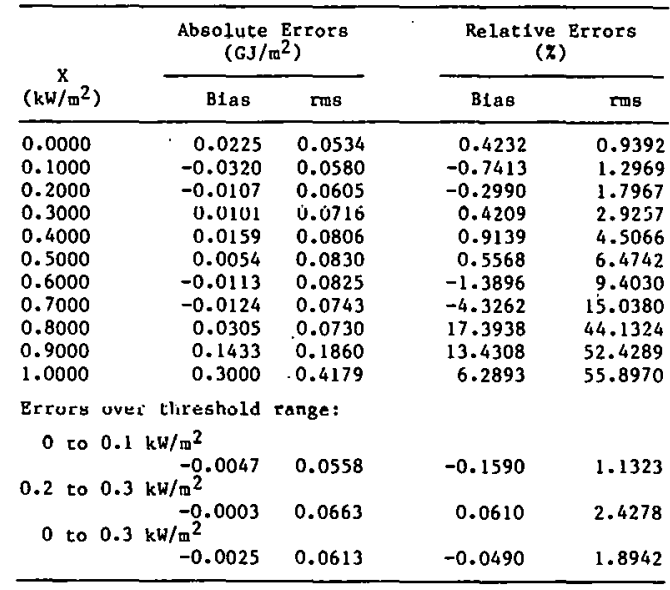

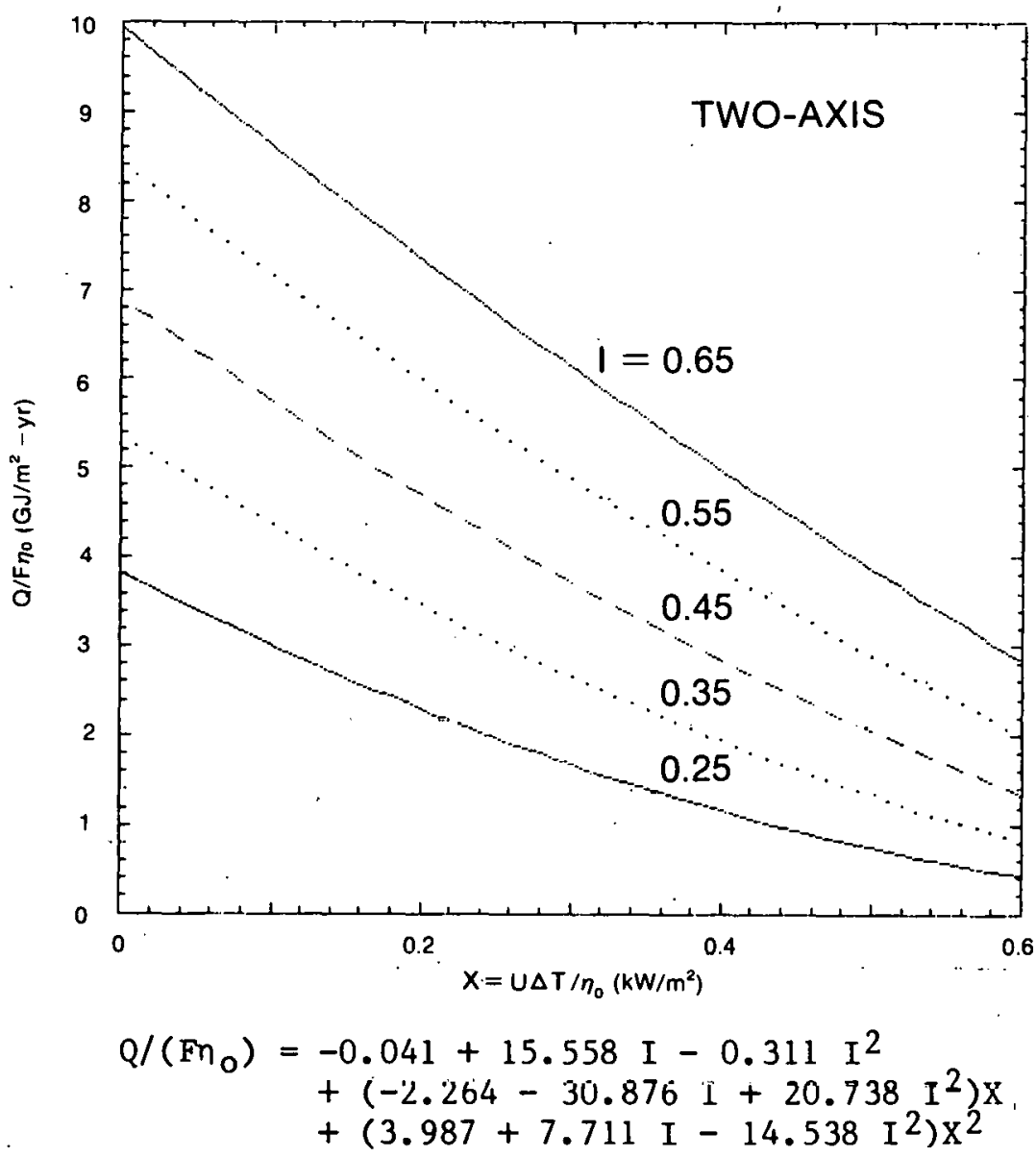

Figure 2-7. Yearly Collectible Energy $Q$ for Concentrator with Two--Axis Tracking, Shown as Graph and as Curve Fit for $Q /\left(F n_{0}\right)$, as Function of Threshold $X$ (in $\mathrm{kW} / \mathrm{m}^{2}$ ), and of Direct Normal Irradiance I (in $\mathbf{k W} / \mathrm{m}^{2}$ ) 


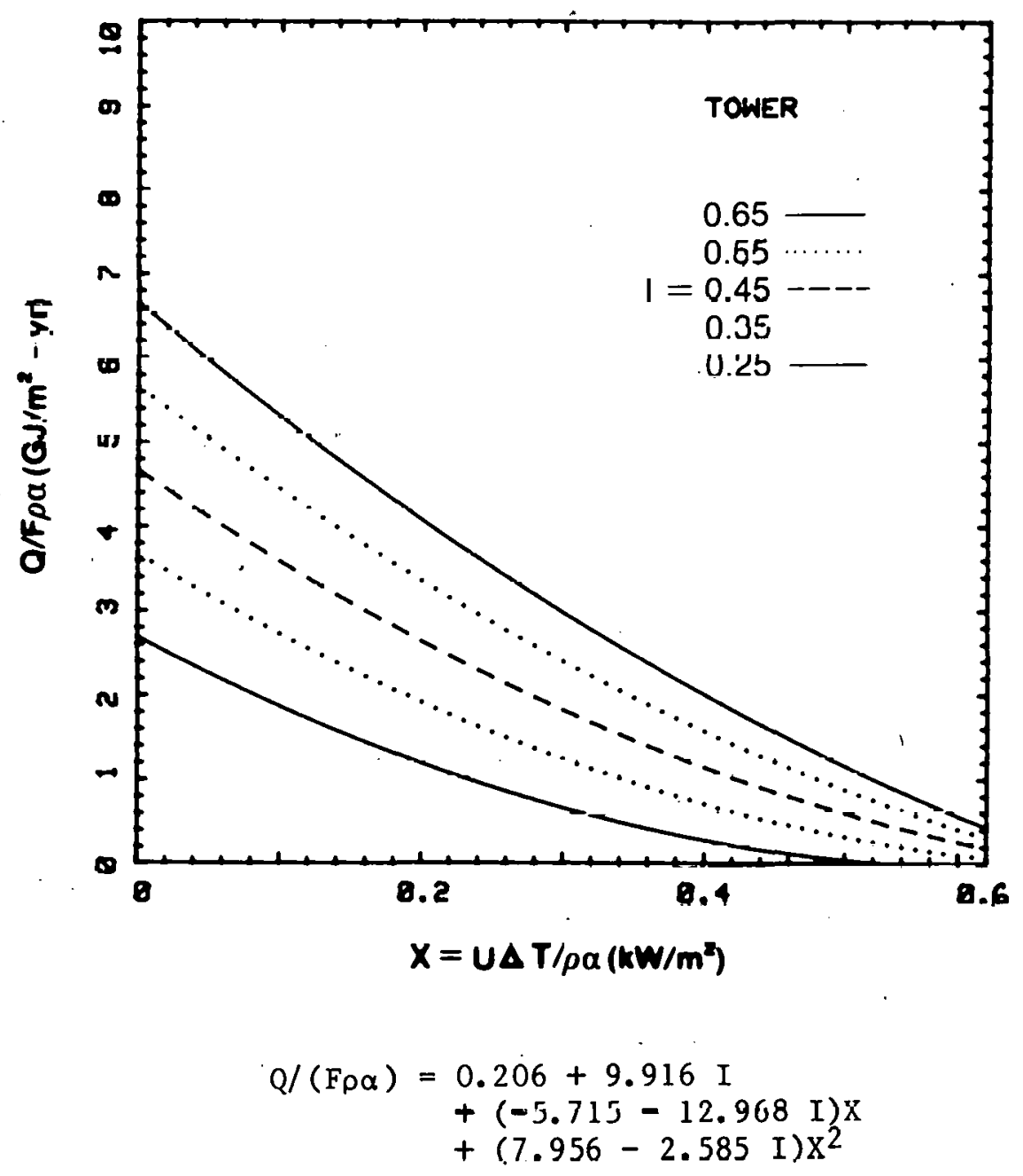

Figure 2-8. Yearly Collectible Energy $Q$ for Central Receiver at $35^{\circ}$ Latitude Shown as Graph and as Curve Fit for $Q /(F p a)$, as a Function of Threshold X (in $\mathbf{k W} / \mathrm{m}^{2}$ ), and of Direct Normal Irradiance I (in $\mathrm{kW} / \mathrm{m}^{2}$ ). 
In addition to the error for each threshold, the tables also list averages of the errors over threshold ranges: 0 to $0.1 \mathrm{~kW} / \mathrm{m}^{2}, 0.2$ to $0.3 \mathrm{~kW} / \mathrm{m}^{2}$, and 0 to $0.3 \mathrm{~kW} / \mathrm{m}^{2}$. The rms errors are typically around $2 \%$ for FLAT PLATE and CPC, and around $2 \%$ to $4 \%$ for tracking collectors.

Validating models of this type necessarily involves an element of circularity. To maximize the accuracy of the model, one must use all available (and reliable) data for constructing the model. Hence the validation must fall back on those same data.

Our results for yearly collectible energy at zero threshold agree with other investigations [29] to the extent to which the same data and assumptions were used. There are some differences, mainly because

- the direct insolation "data" used in previous investigations were based on an earlier model; and

- the previous investigations did not include incidence angle modifiers and shading effects.

\subsection{EFFECT OF VARIABLE THRESHOLD}

The simulation described above assumes a constant threshold

$$
\mathrm{X}=\mathrm{U}\left(\mathrm{T}_{\mathrm{col1}}-\mathrm{T}_{\mathrm{a}}\right) / \mathrm{n}_{0}
$$

In a real system the threshold will, however, vary both with ambient and with collector temperature. To understand the effect of threshold variations, we note that the long-term average energy collectible during a particular day or month of the year can also be correlated by equations of the Eq. 2-15 type; of course the coefficients will depend on an additional variable, the solar declination $\delta$ at that time of the year.* Now let us assume that the monthly collectible energy $Q_{\text {month }}$ has been correlated with a constant threshold in the form

$$
\begin{aligned}
Q_{\text {month }}(T, X)= & a_{1}+a_{2} I+a_{3} I^{2}+\left(a_{4}+a_{5} I+a_{6} I^{2}\right) X \\
& +\left(a_{7}+a_{8} I+a_{9} I^{2}\right) X^{2} .
\end{aligned}
$$

(The dependence of the coefficients $a_{i}$ on $\delta$ and $\lambda$ need not be indicated for this discussion.) If the threshold varies from day to day, one can calculate the monthly total by using Eq. 2-21 (suitably normalized by the number of days in the month) for each day with the actual insolation and threshold for each day. The question is whether the monthly average $\overline{Q(I, X)}$ calculated by this method agrees with the approximation of simply_calculating Eq. 2-21 at the monthly average insolation $\bar{I}$ and threshold $\bar{X}$; in other words, is the approximation $Q(I, X) \approx Q(\bar{I}, \bar{X})$ justified?. This is obviously true for the linear terms in Eq. 2-21. For the nonlinear term it involves replacing the

* To make the current method applicable to monthly calculations, we recommend that correlations of the type (2-21) be developed. 
average of a product by the product of averages, e.g., $\overline{\text { (IX) }}+\bar{I} \bar{X}$. This is a good approximation ias long as the variations of the individual variables about their average are sufficiently small. This is indeed the case in many solar energy applications, and it allows many simplifications. In the present case, it permits use of the average threshold even when the actual threshold varies.

To validate this conjecture, we have repeated the simulation with four types of threshold variations

$$
\begin{aligned}
& \mathrm{X}_{1}=\overline{\mathrm{X}}\left[1+\frac{1}{2} \cos \left(\frac{2 \pi \mathrm{DAY}}{365}\right)\right] \\
& \mathrm{X}_{2}=\overline{\mathrm{X}}\left[1-\frac{1}{2} \cos \left(\frac{2 \pi \mathrm{DAY}}{365}\right)\right] \\
& \mathrm{X}_{3}=\overline{\mathrm{X}}\left[1+\frac{1}{2} \sin \left(\frac{\pi \text { HUUR }}{12}\right)\right] \\
& \mathrm{X}_{4}=\overline{\mathrm{X}}\left[1+\frac{1}{4} \cos \left(\frac{2 \pi \mathrm{DAY}}{365}\right)+\frac{1}{4} \sin \left(\frac{\pi \text { HOUR }}{12}\right)\right] .
\end{aligned}
$$

These variations represent typical seasonal and daily patterns, and the ratio between maximum and minimum is quite large, three to one. The results are summarized in Table 2-8 for the flat plate because in practice the flat plate will experience the greatest threshold fluctuations, especially in domestic hot water installations. The results indicate that threshold variations have only a minor effect. For variations $x_{3}, E q \cdot(2-22 c)$, and $x_{4}, E q \cdot(2-22 d)$, the errors are essentially the same as for constant threshold. For variations $\mathrm{X}_{1}$

\begin{tabular}{|c|c|c|c|}
\hline $\begin{array}{l}\text { Average } \\
\text { Threshold }\end{array}$ & Threshold Variation, Eq. 2-22 & $\begin{array}{c}\text { Bias } \bar{\varepsilon}(\%) \\
\mathrm{Eq} \cdot 2-17\end{array}$ & $\begin{array}{l}\varepsilon_{\mathrm{rms}}(\%) \\
\mathrm{Eq}, 2-19\end{array}$ \\
\hline \multicolumn{4}{|c|}{$\bar{x}=0.1 \mathrm{~kW} / \mathrm{m}^{2}$} \\
\hline & $\begin{array}{l}\mathrm{X}_{0}=\text { constant } \\
\mathrm{X}_{1} \propto 1+\cos (\mathrm{day}) \\
\mathrm{x}_{2} \propto 1-\cos (\mathrm{day}) \\
\mathrm{X}_{3} \propto 1+\sin \text { (hour) } \\
\mathrm{x}_{4} \propto 1+\cos \text { (day) }+\sin (\text { hour })\end{array}$ & $\begin{array}{r}-1.6 \\
0.6 \\
-2.8 \\
-1.0 \\
-0.4\end{array}$ & $\begin{array}{l}2.3 \\
1.5 \\
3.6 \\
1.9 \\
1.5\end{array}$ \\
\hline \multicolumn{4}{|c|}{$\bar{X}=0.2 \mathrm{~kW} / \mathrm{m}^{2}$} \\
\hline & $\begin{array}{l}\mathrm{X}_{0}=\text { constant } \\
\mathrm{X}_{1} \propto 1+\cos (\mathrm{day}) \\
\mathrm{X}_{2} \propto 1-\cos (\mathrm{day}) \\
\mathrm{X}_{3} \propto 1+\sin (\text { hour }) \\
\mathrm{X}_{4} \propto 1+\cos (\text { day })+\sin (\text { hour })\end{array}$ & $\begin{array}{r}-1.2 \\
4.3 \\
-4.1 \\
0.3 \\
1.6\end{array}$ & $\begin{array}{l}2.0 \\
4.8 \\
5.1 \\
1.7 \\
2.2\end{array}$ \\
\hline
\end{tabular}
and $\mathrm{X}_{2}$ the rms error is still quite sma1l, and it could be reduced further by simply correcting the correlation according to the corresponding bias.

Table 2-8. ERRORS DUE TO THRESHOLD VARIATTONS FOR FLAT-PLATE COLLECTOR 


\subsection{ADDI TIONAL COMMENTS}

The principal difficulty of this analysis lies in choosing the variables and the number of coefficients for the polynomial fits. With a finite data base, one does not necessarily improve a fit by increasing the number of coefficients; instead, one may be fitting spurious fluctuations. This problem, fitting the noise rather than the actual trend, is particularly serious if the $f$ it is nonlinear and if the data base is not uniformly distributed over the range of variables that one is trying to fit. To check for that possibility, we have plotted in Fig. 2-9 the distribution of the 26 SOLMET stations in latitude $\lambda$ and average beam irradiance $I$. For low and intermediate insolation values, latitudes are distributed fairly uniformly. from $25^{\circ}$ to $48^{\circ}$. Highinsolation values, $I \geq 0.5 \mathrm{~kW} / \mathrm{m}^{2}$, are however represented between $30^{\circ}$ and $40^{\circ}$ only. Given this distribution of stations, a fit with constant and linear terms in insolation and with constant, linear, and quadratic terms in latitude seems reasonable. The model is expected to be reliable in the region where data are available; extrapolation beyond that region has to be done with caution. The domain of high insolation and high latitude is of little interest, because such conditions do not seem to occur. On the other hand, extrapolation below $25^{\circ}$, for all insolation conditions, would be relevant for many applications outside the United States. Within the utilizability model $[7,11]$, the yearly collectible energy for collectors other than EAST WEST, POLAR, and TWO-AXIS has been found to increase with decreasing latitude, the increase being less pronounced at lower latitudes and leveling off near the equator. The present correlations attempt to capture this trend by including a second-order term in latitude, but naive extrapolation below $25^{\circ}$ is likely to result in overprediction. As a lower bound for the yearly collectible energy between $25^{\circ} \mathrm{N}$ and $25^{\circ} \mathrm{S}$, we recommend, instead, the value of $Q$ calculated for $\lambda=25^{\circ}$. Assuming symmetry between collectible energy in the Northern and Southern Hemispheres, the present fits can be used between $25^{\circ} \mathrm{S}$ and $45^{\circ} \mathrm{S}$ if the latitude is inserted as absolute value.

There are no clear-cut general rules for deciding which combination of variables to include in a fitting procedure. We have tried several alternatives, for example, three terms for latitude $x$ three terms for insolation, and two terms for latitude $x$ three terms for insolation. For the collectors with signlficant latitude depcndence, the fit with threp terms for latitude $x$ two terms for insolation appears to be the best in terms of yielding small rms errors without introducing susp1c1ous features. We considered a fit suspect if the individual coefficients were so large in absolute value that results arise from cancellations between large terms of opposite sign. Such a fit may be a poor interpolating function even though it fits the original data with little error. A smoother fit, i.e., one with smaller coefficients, is less problematic in this regard. We also considered a fit suspect if it did not reproduce the expected pattern in latitude and insolation; for example, if the latitude dependence reversed around $30^{\circ}$.

For the EAST WEST, POLAR, and TWO-AXIS collectors, the constraint of constant ground cover ratio introduces a slight latitude dependence, especially at large latitudes. However, this did not seem significant enough to justify a latitude term in these fits. Without latitude dependence, the data base was large enough for incluring a quadratic insolation term instead. 


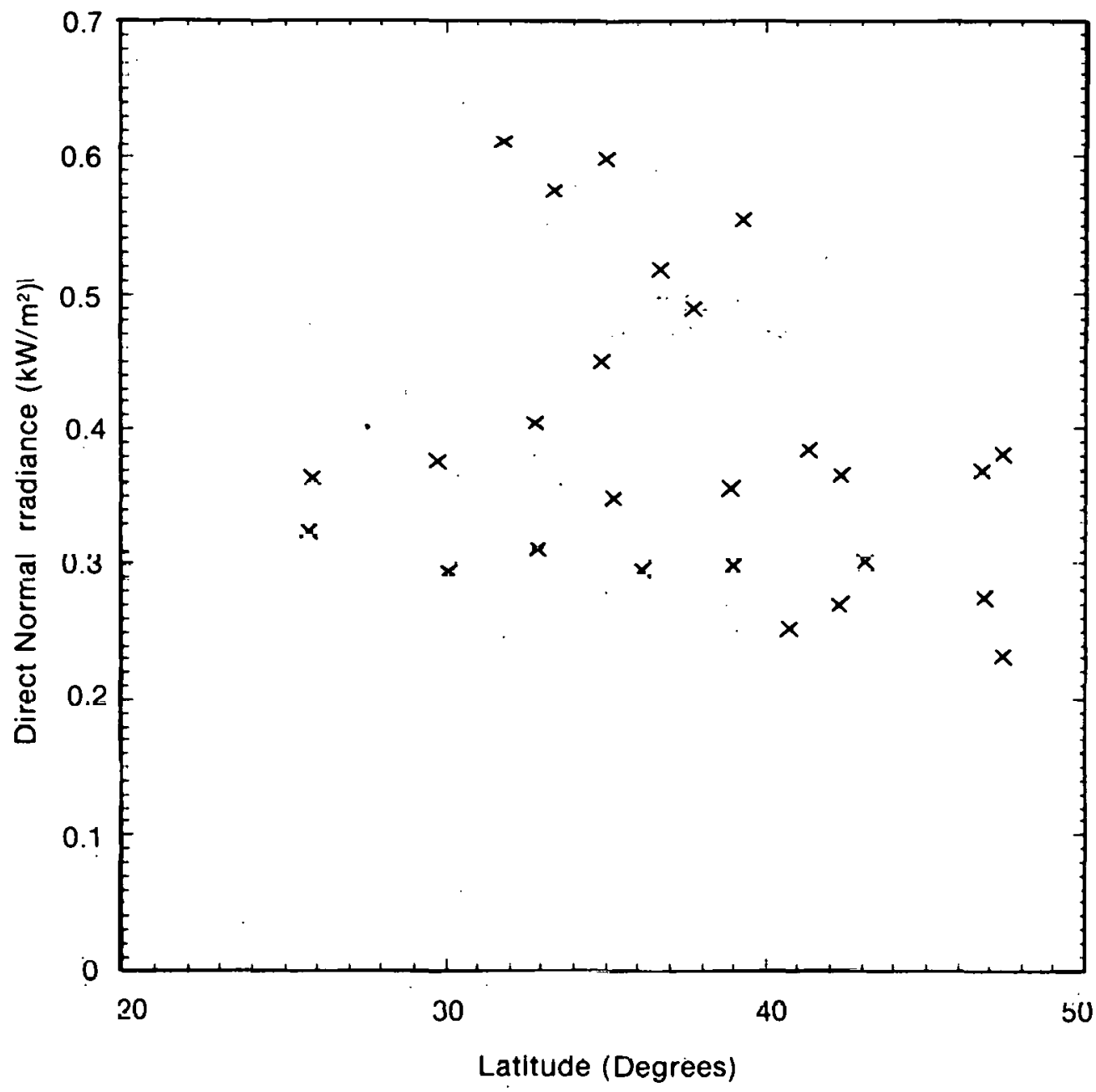

Figure 2-9. Distribution of the Values of Insolation and Latitude for the 26 SOLMET Stations.

Since these correlations will be used mostly for small thresholds, it is natural to ask whether the fits could be improved hy pxrluring the large threshold region. The gain in accuracy achieved by excluding all $x>0.6$ $\mathrm{kW} / \mathrm{m}^{2}$ was noticeable but not large. Fits over the range from $\mathrm{X}=0$ to $\mathrm{X}=0.6$ $\mathrm{kW} / \mathrm{m}^{2}$ seem to be a fair compromise between accuracy and general applicability.

In the utilizability model, $Q$ is correlated with hemispherical insolation on the horizontal surface through the clearness index $\mathrm{K}_{\mathrm{T}}$ of Eq. 2-2. This choice of a correlation parameter was natural as long as beam insolation data were missing. A correlation with beam insolation is expected to be better for focusing collectors. This has been confirmed during the course of this work by comparing fits versus clearness index with fits versus beam insolation. For concentrating collectors, the fits versus beam insolation are approximately one percentage point lower in rms error than those versus clearness index; for flat plates, both beam insolation and clearness index yielded equally good fits. Hence we have chosen beam insolation as the correlation parameter. A contour map of yearly average beam irradiance values for the United States is 
provided in Fig. 2-10. To. make the present correlations accessible to users without data of yearly average beam insolation, we have included Fig. 2-11 with the correlation between yearly average beam irradiance $I$ and yearly average clearness index $\overline{\mathrm{K}}_{\mathrm{T}}$ for the 26 SOLMET stations, $\overline{\mathrm{K}}_{\mathrm{T}}$ being defined as

$$
\overline{\mathrm{K}}_{\mathrm{T}}=\frac{1}{365.25} \sum_{\substack{\text { days } \\ \text { of year }}} \frac{\mathrm{H}}{\mathrm{H}_{\mathrm{o}}} \text {. }
$$

This correlation is

$$
\mathrm{I}=-0.34+1.37 \overline{\mathrm{K}}_{\mathrm{T}}
$$

with $\mathrm{I}$ in $\mathrm{kW} / \mathrm{m}^{2}$. If only the number of hours of sunshine is known, one can use a similar correlation with hours of sunshine, due to Angstrom (see Duffie and Beckman, Ref. 9).

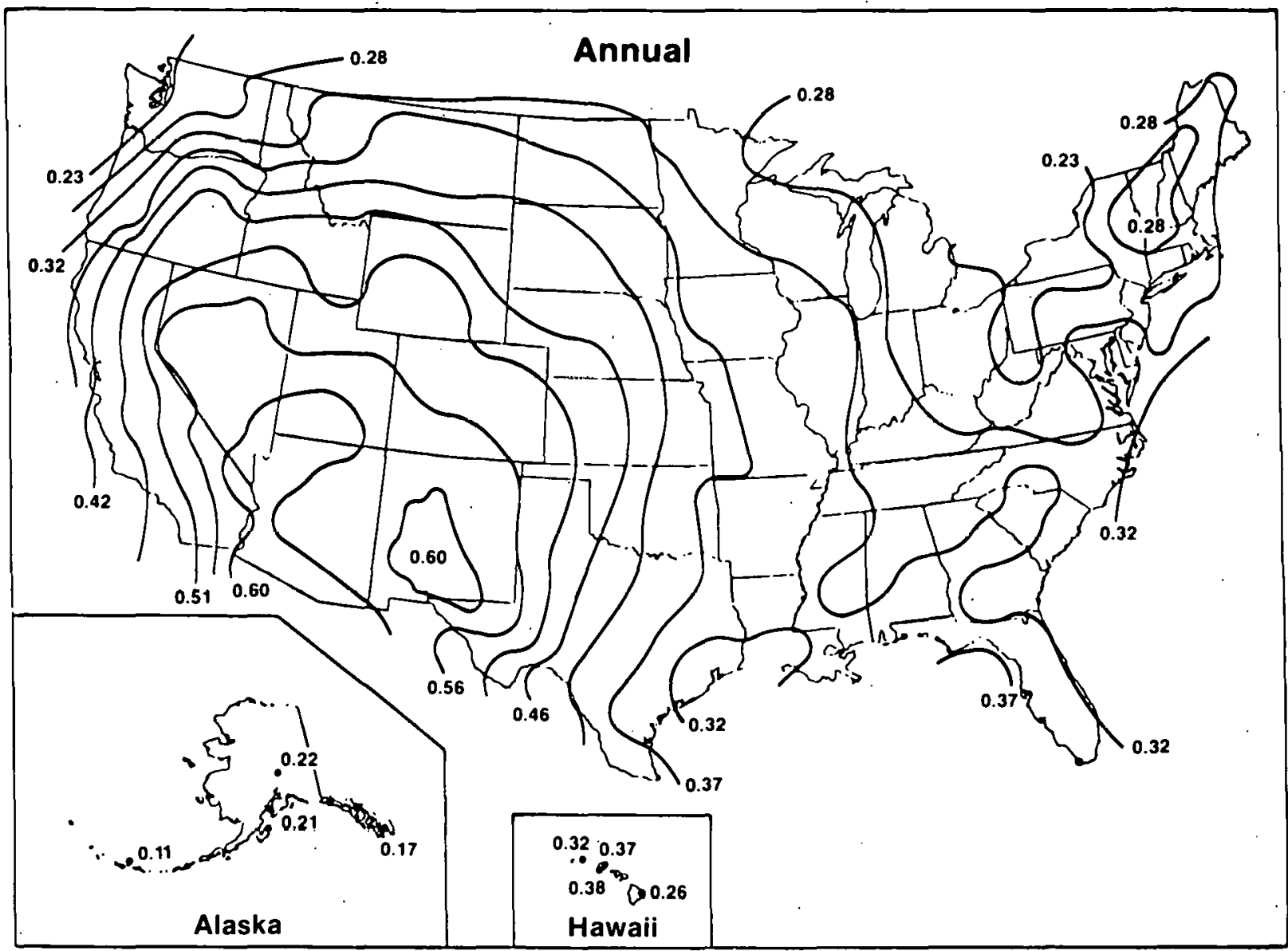

Figure 2-10. Yearly Average Direct Normal Irradiance I (in $\mathrm{kW} / \mathrm{m}^{2}$ ) During Daylight Hours for the United States.

(I thank R. Hulstrom of SERI for kindly providing a copy of this map before publication.) 


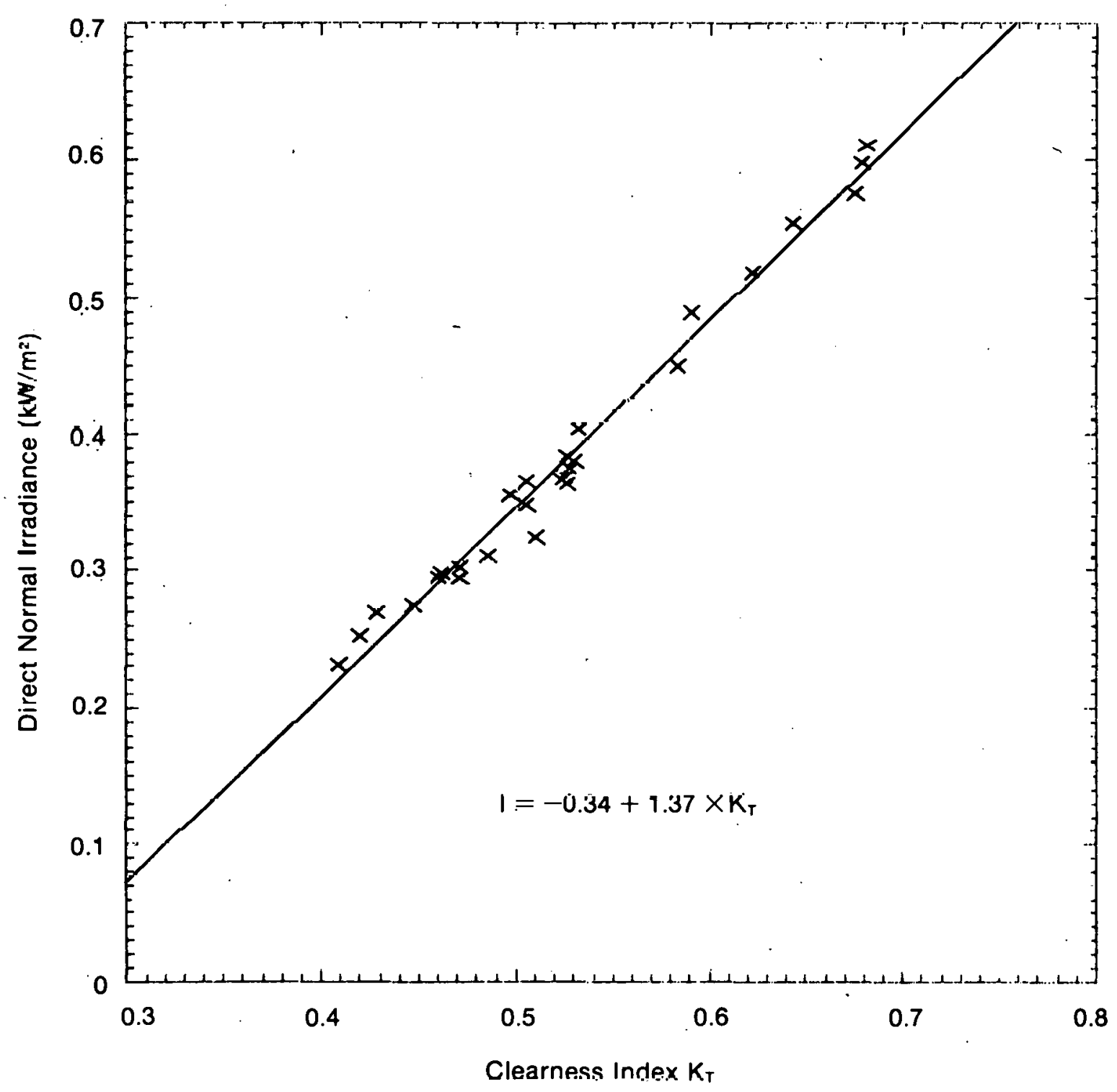

Figure 2-11. Correlation between Yearly Average Clearness Index $K_{T}$ and Yearly Average Direct Normal Solar Irradiance I during Daytime, for the 26 SOLMET Stations. 
SECTION 3.0

CONCLUSION--EXAMPLES

The correlations developed in this paper can be used for any system where (i) the collector operates year-round and no collected energy is discarded and (ii) the collector operation can be characterized by either constant efficiency (photovoltaic systems) or by a specifled average threshold (thermal systems). Operation according to condition (i) is certainly desirable in order to maximize the useful energy per invested capital. This condition can be satisfied, exactly or at least to good approximation, in the following applications :

- generation of electric or mechanical power,

- industrial process heat,

- hot water for domestic and commercial buildings.

Condition ( $i$ ) is not satisfied by systems for solar heating or cooling. We now illustrate the use of our correlations by examples of photovoltaic and thermal systems.

\subsection{PHOTOVOLTAIC SYSTEMS}

The conversion efficiency of a photovoltaic cell is nearly independent of insolation. Once the yearly average temperature of the cell has been determined for a given cell design and cell cooling mode, one can approximate the corresponding cell efficiency by a constant $n_{c}$. The yearly electricity production is then obtained by multiplying the yearly available insolation $Q_{0}$ for the collector type in question by $n_{c} \cdot Q_{0}$ can be obtained from Figs. 2-2 to 2-8 by setting $X=0$ and $F_{0}=1$. However, a different graph, Fig. 3-1, is more convenient because it shows $Q_{0}$ directly, as a function of yearly average beam irradiance during daylight hours I, for FLAT PLATE, EAST WEST, TWO-AXIS, and TOWER [31].

As an example, consider a flat-plate photovoltaic panel at a tilt angle equal to the latitude and with cell efficiency $n_{c}=10 \%$. From the contour map in Fig. 2-10, one sees that the sunniest region of the United States has insolation values around $I=0.6 \mathrm{~kW} / \mathrm{m}^{2}$. Reading the solid line in Fig. $3-1$ corresponding fo $\lambda=35^{\circ}$ (Albuquerque), one finds an available solar irradiation of $8.0 \mathrm{GJ} / \mathrm{m}^{2}$. The corresponding electricity production is

$$
\mathrm{Q}_{\mathrm{e}}=\mathrm{n}_{\mathrm{c}} \mathrm{Q}_{\mathrm{o}}
$$

which is $0.80 \mathrm{GJ} / \mathrm{m}^{2}$. The lowest beam irradiance occurs in the Northwest and Northeast. Reading the solid line corresponding to $\lambda=45^{\circ}$ and $\mathrm{I}=0.23 \mathrm{~kW} / \mathrm{m}^{2}$ (northern part of New York State), one finds an electricity production of 0.42 $\mathrm{GJ} / \mathrm{m}^{2}$ for the same cell efficiency.

As a second example, take a parabolic dish with rim angle $40^{\circ}$, geometric concentration ratio 1000, and total optical error characterized by an rms beam spread of 7 mrad. Assume a high-efficiency cell with $n_{c}=25 \%$ and a 


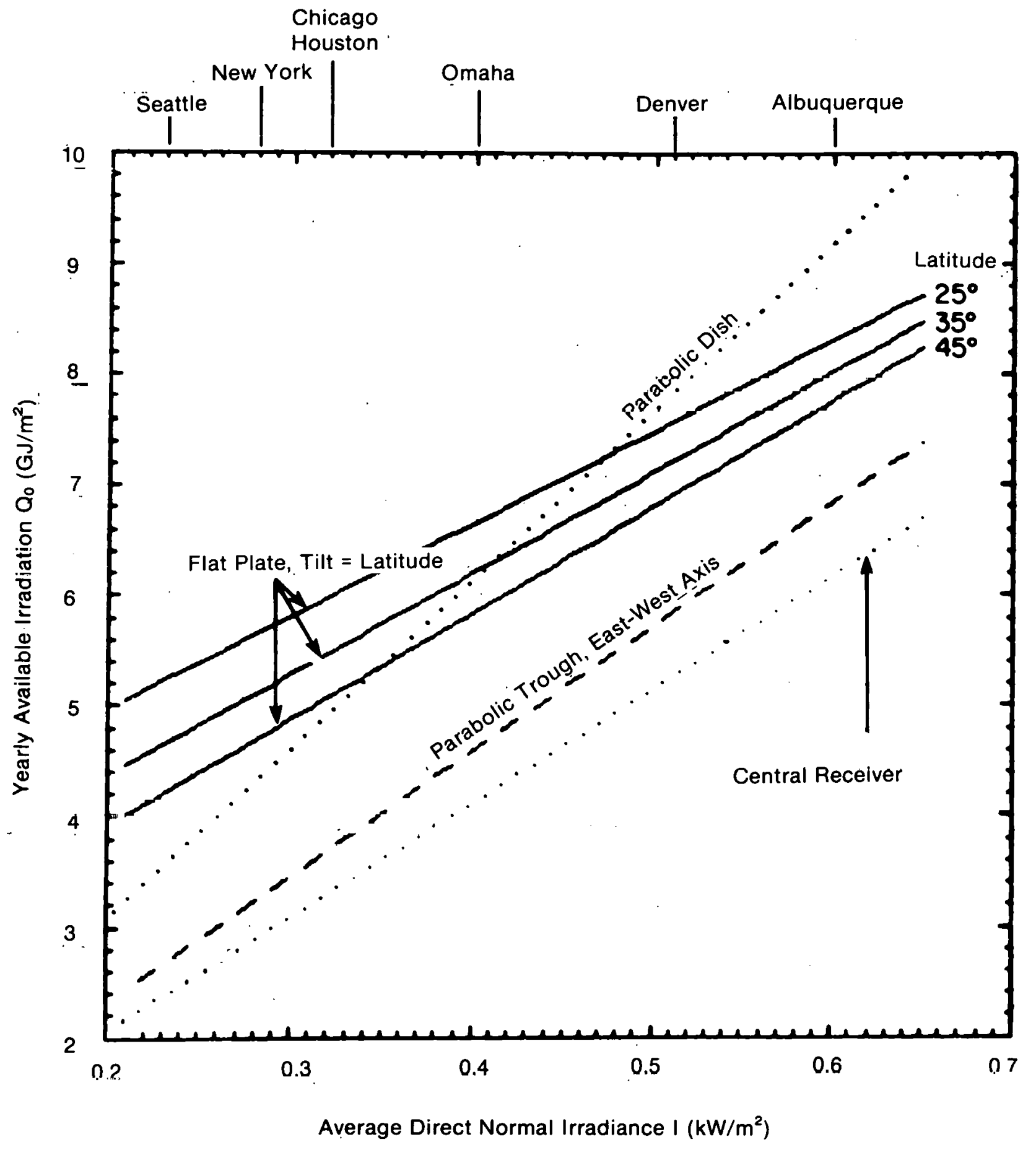

Figure 3-1. Yearly Total Solar Irradiation $Q_{0}$ Available to Flat Plate, Concentrator with East-West Tracking, and Central Receiver [31], as Function of Annual Average Daytime Direct Normal Solar Irradiance I.

This graph shows radiation availability only. Central receiver curve includes intercept factor. In normal applications the output of parabolic dish and of central receiver will differ much less because of different system losses. 
reflectance of the reflector of $\rho=0.9$. Let us include the effect of circumsolar radiation, since doubts have frequently been raised about the loss of performance of focusing collectors in regions with high circumsolar radiation. The correlations for the available irradiation $Q_{0}$ for focusing collectors are based on pyrheliometer data and require correction factors if the acceptance half-angle of the collector is smaller than the $2.6^{\circ}$ acceptance half-angle of the pyrheliometer. This correction factor is given by the intercept factor (Eq. 7-3 of Ref. 20),

$$
\gamma_{\mathrm{av}}=\frac{\gamma_{\mathrm{s}, \mathrm{av}}-\left(\gamma_{\mathrm{s}, \mathrm{av}}-\gamma_{\mathrm{c}, \mathrm{av}}\right) R_{\mathrm{av}}(\mathrm{X})}{1-0.0963 \mathrm{R}_{\mathrm{av}}(\mathrm{X})}
$$

where $R_{a v}(X)$ is the long-term average circumsolar ratio for the location in question, and $\gamma_{s, a v}$ and $\gamma_{c}$, av are the intercept factors for the solar disk and for the circumsolar region. Numerical values for $\gamma_{s}$ av and $\gamma_{c}$, av are listed in Table 6-1 of Ref. 20 for typical parabolic dish designs; for the present example, they are

$$
Y_{\mathrm{s}, \mathrm{av}}=0.9738
$$

and

$$
\gamma_{\mathrm{s}, \mathrm{av}}-\gamma_{\mathrm{c}, \mathrm{av}}=0.4424
$$

The monthly average circumsolar ratios $R_{a v}(X)$ are listed in Table 4-3 of Ref. 20 as a function of threshold $X$ for all locations for which data are currently available. For photovoltaic applications, the appropriate threshold is $X=0$. Assuming that a simple average over all of the months listed in Table 4-3 of Ref. 20 is a fair indication of the long-term yearly average, we find a value $R_{a v}(X=0)=0.040$ for Albuquerque, a location with very low circumsolar radiation. This yields an intercept factor of $\gamma_{\text {av }}=0.960$. Of the insolation $Q_{0}=9.2 \mathrm{GJ} / \mathrm{m}^{2}$ (Fig..3-1) available to a two-axis tracking concentrator, a fraction $\rho \gamma_{a v}$ is reflected by the reflector and intercepted by the re.11, and hence the electricity production is

$$
\begin{aligned}
Q_{e} & =\rho \gamma_{a v} n_{c} Q_{o} \\
& =1.99 \mathrm{GJ} / \mathrm{m}^{2}
\end{aligned}
$$

if $\rho=0.90$ and $n_{c}=0.25$.

nf the lncations for which circumsolar radiation measurements have been made, Argonne (near Chicago), IL, has the highest circumsolar ratio, 0.108 averaged over the months in Table 4-3 of Ref. 20. The corresponding intercept factor is 0.936 , just a little smaller than for Albuquerque. The available insolation $\mathrm{Q}_{0}=4.98 \mathrm{GJ} / \mathrm{m}^{2}$ is, of course, much lower at Argonne, and the electricity production is $Q_{e}=1.05 \mathrm{GJ} / \mathrm{m}^{2}$. 


\subsection{THERMAL SYSTEMS}

Thermal collectors can be characterized by an efficiency equation of the form

$$
\hat{n}=n_{0}-U\left(T_{r}-T_{a}\right) / I_{c o l 1},
$$

where

$$
\begin{aligned}
& \eta_{0}=\text { optical efficiency; } \\
& \mathrm{T}_{\mathrm{r}}=\text { receiver surface temperature; } \\
& \mathrm{T}_{\mathrm{a}} \text { - ambiénl Lemperature; }
\end{aligned}
$$

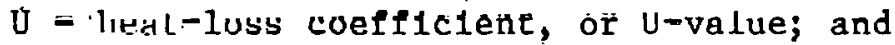

$$
\begin{aligned}
& I_{c o l 1}=\text { insolation on collector aperture. }
\end{aligned}
$$

The U-value depends only weekly on $\mathrm{T}_{\mathbf{r}}$ and $\mathrm{T}_{\mathbf{a}}$, and, in practice, a good approximation is obtained by treating it as a constant.*

Usually it is more practical to measure the fluid temperature than the receiver surface temperature. In terms of the mean fluid temperature $T_{f}$, the efficiency equals

$$
n=F^{\prime}\left[n_{0}-U\left(T_{f}-T_{a}\right) / I\right],
$$

where F', called collector efficiency factor in Ref. 9, is given by the ratin

$$
F^{\prime}=\frac{I_{\mathrm{f}} \mathrm{fa}}{\mathrm{U}}
$$

of the thermal conductance $U_{f a}$ from fluid to ambient over the thermal conductance from receiver surface to ambient (in this equation both U-values must refer to aperture area). If the fluid inlet temperature $T_{L_{u}}$ is sperified, the erficiency is

$$
n=F_{R}\left[n_{0}-U\left(T_{i n}-T_{a}\right) / I\right],
$$

with the heat removal factor

* Sometimes test results are reported according to a second-order fit with temperature-dependent $U$-value. A convenient translation from a second-order fit to a linear one can be found in. Ref. 21 . 


$$
\mathrm{F}_{\mathrm{R}}=\frac{\dot{\mathrm{mc}} \mathrm{p}}{\mathrm{U} \Lambda}\left[1-\exp \left(\frac{-\mathrm{UAF}^{\prime}}{\dot{\mathrm{m}}_{\mathrm{p}}}\right)\right] \text {, }
$$

where $\dot{\mathrm{m}}$ is the mass flow rate $(\mathrm{kg} / \mathrm{s})$ through the collector and $\mathrm{c}_{\mathrm{p}}$ is the fluid heat capacitance $\left(\mathrm{J} / \mathrm{kg}^{\circ} \mathrm{C}\right)$ at constant pressure.

While a standard collector test procedure [1] determines only the parameters of a single collector module, the performance calculation for an actual installation must include losses from heat transfer lines between collector and point of use. Beckman [22] has shown how to account for this by a straightforward modification of $\eta_{0}$ and $U_{0}$. The effects of a heat exchanger can be treated in analogous fashion by Dewinter's heat exchange factor [30].

For consistency with our assumptions, it is important that the reader use the correct insolation specification for $I_{\text {coll }}$. For flat-plate collectors, $I_{c o l l}$ represents the hemispherical irradiance $I_{h}$; for tracking collectors, it is the beam irradiance $I_{b}$; and for $C P C s$, it is the irradiance within the acceptance angle $I_{b}+(1 / C) I_{d}$. If the collector test data are not reported according to this convention, correction terms must be applied to the optical efficiency (see the Appendix of Ref. 7).

The three equations, $3-3,3-4$ and $3-6$, can be summarized in the form:

$$
n=F\left[n_{0}-U\left(T_{\operatorname{col} 11}-T_{a}\right) / I_{\operatorname{col} 11}\right],
$$

where

$$
F=\left\{\begin{array}{lll}
1 & \text { for } & \mathrm{T}_{\mathrm{col1}}=\mathrm{T}_{\mathrm{r}} \\
\mathrm{F}^{\prime} & \text { for } & \mathrm{T}_{\mathrm{col1}}=\mathrm{T}_{\mathrm{f}} \\
\mathrm{F}_{\mathrm{R}} & \text { for } & \mathrm{T}_{\mathrm{col1}}=\mathrm{T}_{\mathrm{in}}
\end{array}\right.
$$

The collector will be turned on whenever the insolation $\mathrm{I}_{\text {coll }}$ exceeds the threshold

$$
\mathrm{X}=\frac{\mathrm{U}\left(\mathrm{T}_{\mathrm{col1}}-\mathrm{T}_{\mathrm{a}}\right)}{\mathrm{n}_{\mathrm{o}}} \text {. }
$$

This is the abscissa ( $x$-axis) of Figs. 2-2 to 2-8. The ordinate ( $y$-axis) shows the yearly collectible energy $Q$ in the form $Q /\left(F n_{0}\right)$ (that this is the appropriate form follows from Eq. 2-11).

To see how the correlations can be used for thermal collectors, consider a parabolic trough for which the following parameters have been measured:

$$
F^{\prime} n_{0}=0.65 \text { and } F^{\prime} U=0.67 \mathrm{~W} / \mathrm{m}^{2}{ }^{\circ} \mathrm{C}
$$


(These are the slope and intercept for the SOLAR KINETICS collector in Fig. 34 of Ref. 23.)

If this collector is to operate in Albuquerque, $N M$, at an average fluid temperature $\mathrm{T}_{\mathrm{f}}=300^{\circ} \mathrm{C}$, the threshold is

$$
\mathrm{X}=0.67 \times(300-13) / 0.65 \mathrm{~W} / \mathrm{m}^{2}=0.294 \mathrm{~kW} / \mathrm{m}^{2},
$$

since the yearly average ambient temperature is $\mathrm{T}_{\mathrm{a}}=13^{\circ} \mathrm{C}$. The yearly average beam insolation is $\mathrm{I}=0.6 \mathrm{~kW} / \mathrm{m}^{2}$, from $\mathrm{Fig} .2-10^{\mathrm{a}}$. Interpolation between the $I=0.55$ and 0.65 curves in Fig. $2-4$ yields $Q / F n_{0}=3.65 \mathrm{GJ} / \mathrm{m}^{2}$. Hence this collector can deliver $Q=2.37 \mathrm{GJ} / \mathrm{m}^{2}$ per year if it is installed with eastwest tracking axis. To illustrate, the effect of dirt and degradation, let us assume that the optical efficiency is reduced by $10 \%$ to $\mathrm{F}^{\prime} n_{0}=0.585$, averaged over the lifetime of the collector, while, the U-value remains constant. Then the threshold Increases to $0.327 \mathrm{~kW} / \mathrm{m}^{2}$ and the yearly output is only $1.96 \mathrm{GJ} / \mathrm{m}^{2}$.

A second example will illustrate the usefulness of these correlations for industrial process heat and for solar thermal power plants.*

Consider an application where water from the water mains is to be heated to $90^{\circ} \mathrm{C}$, e.g., for cleanup operations in the food industry. The inlet temperature $\mathrm{T}_{\text {in }}$ of the collector is nearly constant, either at the yearly average ambient $\mathrm{T}_{\mathrm{a}}$ or at a constant amount above $\mathrm{T}_{\mathrm{a}}$ if a heat recovery unit is installed as a conservation measure. Flow rate $\dot{m}$ and collector area $A$ are

*Most applications of process heat. in industry have an essentially constant load during daylight hours, and hence storage is not needed to improve collector utilization. Also, in many existing plants the energy collectible on the available land does not even meet the load; in such cases it is pointless to add any storage beyond a buffer for smoothing transients. In the foreseeable future; energy storage in the form of gas or oil will cost less than thermal storage, and the least expensive solar energy system wi1.1. use the collector as preheater wth little or no storage. For solar thermal power plants, the situation is similar. Storage of a few hours would be desirable to improve the match between solar input and air conditioning load; however, such storage is expensive because high conversion efficiency is important, which in turn requires high temperatures (preferably above $500^{\circ} \mathrm{C}$ ) [24]. The fact that these applications are likely to use little or no storage implies fairly. constant inlet temperatures to the collector. This situation stands in marked contrast with solar hot water or space heating, where the load is out of phase with the solar input, and storage on the order of one day is necessary for any reasonable collector utilization. Here the collector inlet temperature depends on insolation and load during the previous day, and varies widely. The reader should note, however, that constancy of operating temperatures is not a precondition for this method, as demonstrated by the smallness of the effect of threshold variations in Table 2-8. 
chosen so that an outlet temperature $\mathrm{T}_{\text {out }}=90^{\circ} \mathrm{C}$ is reached only under peak insolation, which typically means

$$
\mathrm{I}_{\mathrm{co11}}=\mathrm{I}_{\max } \approx 1 \mathrm{~kW} / \mathrm{m}^{2}
$$

Combining this condition, i.e:,

$$
A n I_{\max }=\dot{m} c_{p}\left(T_{\text {out }}-T_{\text {in }}\right) \text {, }
$$

with Eqs. (3-5) and (3-6) for $n$ and $F_{R}$ yields the flow rate-heat capacitance product $\operatorname{mc}_{\mathrm{p}}$ as

$$
\dot{\mathrm{m}} \mathrm{c}_{\mathrm{p}}=\frac{\mathrm{UAF}^{\prime}}{\ln \left[\frac{\eta_{0} I_{\max }-U\left(T_{\text {in }}-T_{a}\right)}{\eta_{0} I_{\max }-U\left(T_{\text {out }}-T_{a}\right)}\right]}
$$

Suppose the collector is a Fresnel lens plus mirror collector in polar mount with the parameters $F^{\prime} \eta_{0}=0.656$ and $F^{\prime} U=0.78 \mathrm{~W} / \mathrm{m}^{2}{ }^{\circ} \mathrm{C}$ as reported in Ref. [26]. Let us assume operation with $T_{i n}=T_{a}$; then the threshold is $X=0$, and one obtains from Eqs. 3-10 and 3-6 the value

$$
F_{R} n_{0}=0.624
$$

From Fig. 2-6, for the POLAR case, we read $Q /\left(F n_{0}\right)=8.15 \mathrm{GJ} / \mathrm{m}^{2}$ for locations with $\mathrm{I}=0.6 \mathrm{~kW} / \mathrm{m}^{2}$; thus the yearly collectible energy is

$$
\mathrm{Q}=5.09 \mathrm{GJ} / \mathrm{m}^{2} \text {. }
$$

For a direct comparison between several typical collectors, we plot in Fig. 3-2 the yearly average energy delivery $Q$ versus operating temperature (as $\Delta \mathrm{T}=\mathrm{T}_{\mathrm{f}}-\mathrm{T}_{\mathrm{a}}=$ difference between fluid and ambient temperatures) at a geographical latitude of $35^{\circ}$. Two climates are shown: (a) a sunny climate with average beam irradiance $I=0.6 \mathrm{~kW} / \mathrm{m}^{2}$ and (b) a fairly cloudy one with $I=0.3 \mathrm{~kW} / \mathrm{m}^{2}$. The collector parameters are listed in Table 3-1; they are typical values based on standard outdoor tests. One of the most striking conclusions from this comparison concerns the crossover between flat-plate and concentrating collectors. At temperatures that are more than approximately $25^{\circ} \mathrm{C}$ above ambient, all of the concentrating collectors in Fig. 3-2 surpass the flat plate in performance. This conclusion holds even for cloudy climates where concentrating collecțors were believed to be at a disadvantage because they miss most or all of the diffuse insolation. The high heat loss of flatplate collectors turns out to be more important: at times when the insolation is above the threshold for a flat-plate collector (with $\Delta \mathrm{T} Z 25^{\circ} \mathrm{C}$ ) there is enough direct radiation to run a concentrating collector. of course, energy delivery is only the denominator of the cost per energy criterion; the choice of a collector will depend just as much on its cost.

We close with some considerations (which should be obvious but are frequently forgotten [27]) about comparing long-term performance predictions with the 
output of real systems. First of all, a long-term performance model cannot be validated or invalidated by short-term data! The model of this paper predicts yearly average collectible energy and can therefore be validated only by data of yearly average performance. This requires an observation period of at

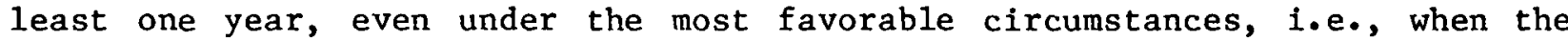
actual weather closely matches the long-term average. In practice, however, weather data for a particular year can differ drastically from the average [28]. Therefore a comparison should be based not on the long-term average insolation, but on the insolation actually measured during the period of observation. Even. then discrepancies are possible, especially for the NORTHSOUTH case, if the seasonal distribution differs from the long-term pattern.

Table 3-1. TYPICAL COLLECTOR PARAMETERS ASSUMED FOR COMPARISON IN FIGURE 3-2 .

\begin{tabular}{lcl}
\hline Collector type & $F^{\prime} n_{0}$ & $F^{\prime} U^{\left[W / m^{20} \mathrm{C}\right]}$ \\
\hline $\begin{array}{l}\text { Flat plate, } \\
\text { double glazed }\end{array}$ & $0.70^{\mathrm{b}}$ & 5.0 \\
$\begin{array}{l}\text { CPC 1.5X with } \\
\text { evacuated tubes }\end{array}$ & $0.60^{\mathrm{c}}$ & $0.75^{\mathrm{c}}$ \\
Parabolic trough & $0.65^{\mathrm{e}}$ & 0.67 \\
Parabolic dish $^{\mathrm{d}}$ & $0.61^{\mathrm{e}}$ & 0.27 \\
Power tower $^{\mathrm{f}}$ & $\rho \alpha=0.81^{\mathrm{g}}$ & 0.16 \\
\hline
\end{tabular}

a Average of 4 best double-glazed collectors, Florida Solar Energy Center, Summary Test Package, issuet 15 Feb. 1970, and supplements 1. (April 1978) and 2 (June 1978).

b with respect to pyranometer.

c Typical values based on test results reported in Ref. 33; opt1cal efficiency with respect to radiation within acceptance angle.

d Typical test results from Ref. 23.

e with respect to pyrheliometer.

f Projected performance [31].

$\mathrm{g} \rho=$ heliostat reflectance

$\alpha=$ receiver absorptance.

Secondly, a performance prediction necessarily assumes that the system actually performs according to design specifications. A real system may, however, suffer all sorts of unforeseen problems such as leaks, pump fallures, tracker malfunctions, and collector degradation, causing the output to fall short of the design goal. In that case it may still be possible to make a meaningful comparison between performance and prediction, but only if the system is adequately instrumented and if all failures and degradation effects are accurately and consistently monitored. 


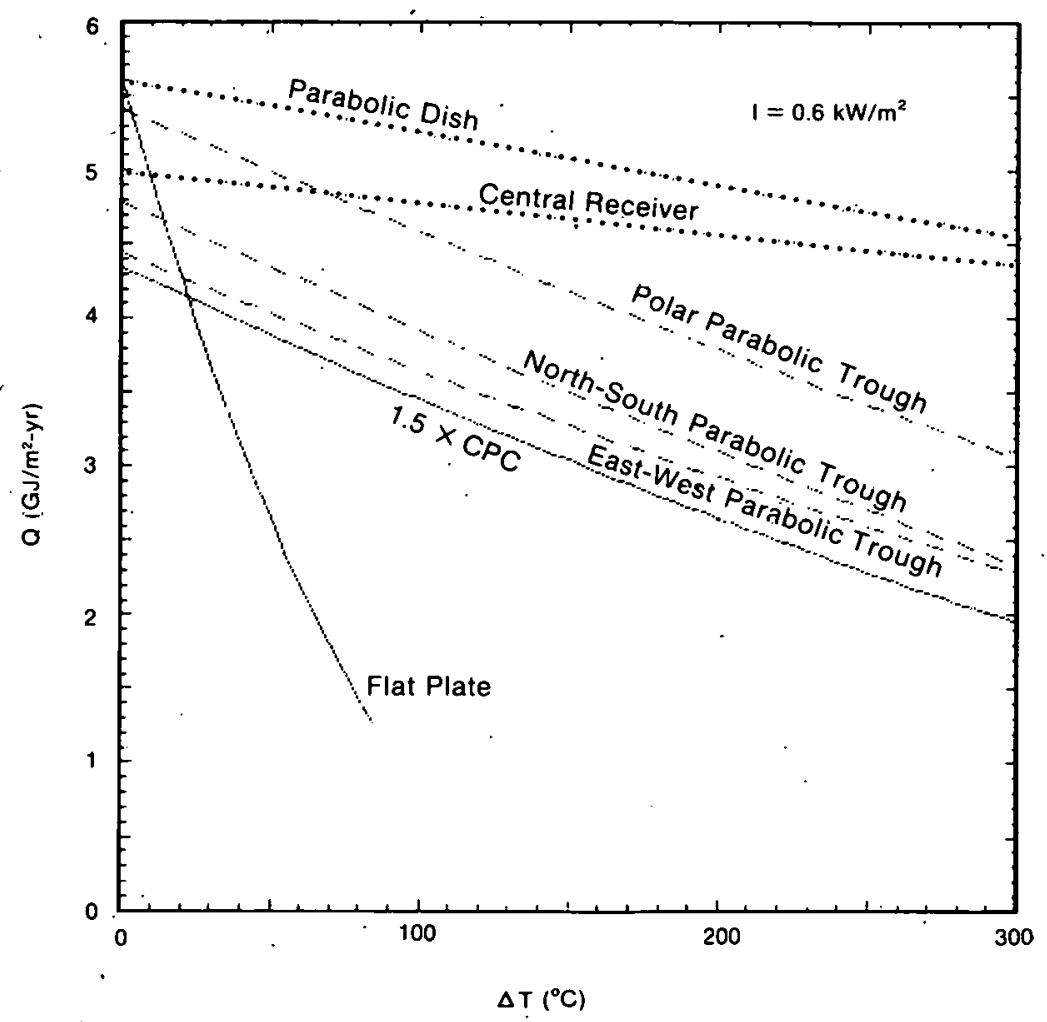

Figure 3-2(a), Yearly Collectible Energy Q Versus Average Difference Between Fluid Temperature and Ambient, for Typical Collectors (for Collector Parameters, see Table 3-1): (a) Average Daytime Direct Normal Irradiance I $=0.6 \mathrm{~kW} / \mathrm{m}^{2}$

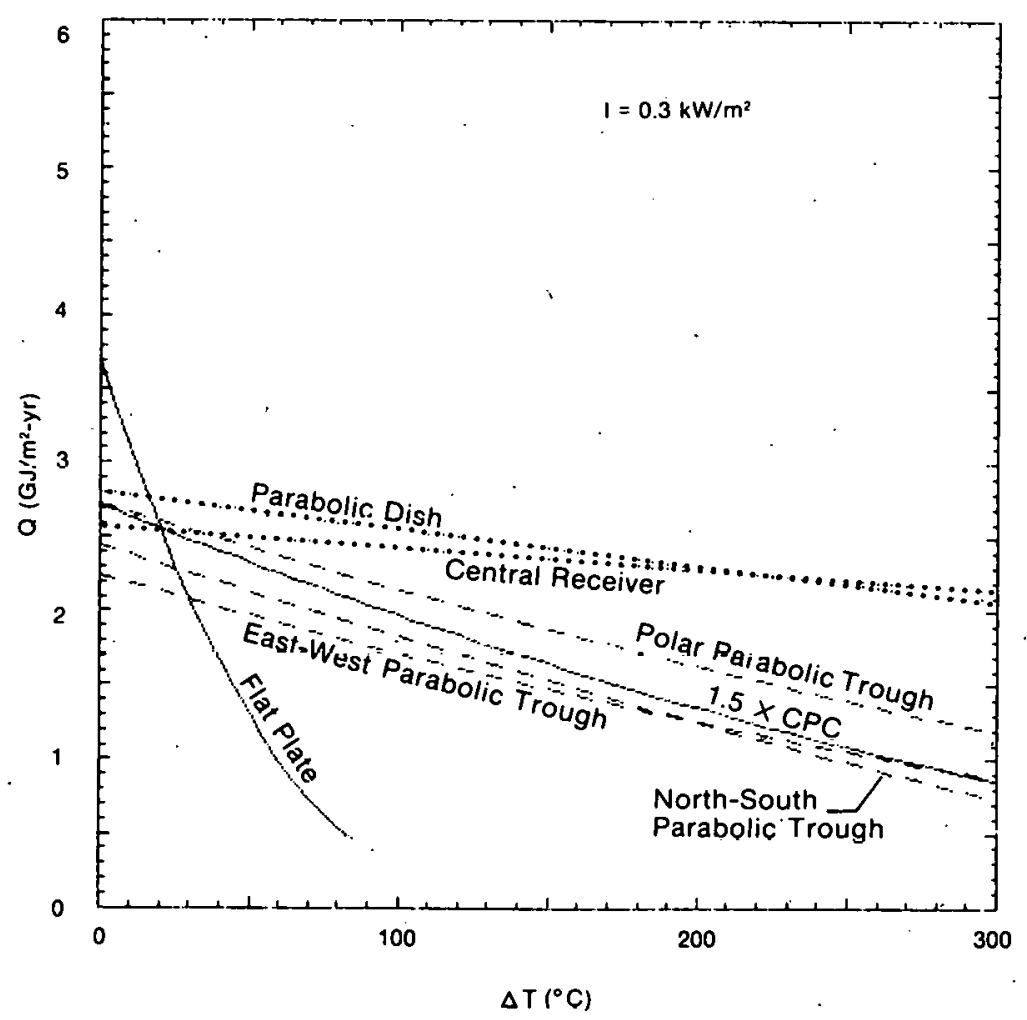

Figure 3-2(b). Average Daytime Direct Normal Irradiance I $=0.3 \mathrm{~kW} / \mathrm{m}^{2}$ 


\section{S=R1数}


SECTION 4.0

REFERENCES

1. ASHRAE Standard 93-77, Collector Test Procedure of the American Society of Heating, Refrigeration and Air Conditioning Engineers, $343 \mathrm{~W}$. $43 \mathrm{rd}$ St. N.Y., N.Y.

See also J. E. Hill and E. R. Streed, "A Method of Testing for Rating Solar Collectors Based on Thermal Performance," Solar Energy 18, 421 (1976).

2. S.A. Klein et al., TRNSYS-A Transient Simulation Program; Users Manual, Engineering Experiment Station Report 38, Solar Energy Laboratory, University of Wisconsin, Madison, WI.

M. E. Fewell and N. R. Grandjean, "User's Manual for Computer Code SOLTES-1 (Simulator of Large Thermal Energy Systems)," Sandia Laboratories Report SAND 78-1315 (June 1979).

3. R. Bruno, "Which Models for What?" Philips GmbH Forschungslaboratorium Aachen, Report No. 7/79, Feb. 1979. Publ. in Proc. Joint GermanAustralian Workshop (CCMS) on Solar Energy System Design.

4. W. A. Beckman, S. A. Klein, and J. A. Duffie, Solar Heating Design by the f-chart Method, Wiley, New York (1977).

5. B. Y. H. Liu and R. C. Jordan, "A Rational Procedure for Predicting the Long Term Average Performance of Flat-Plate Solar-Energy Collectors." Solar Energy 7, 53 (1963).

H. C. Hottel and A. Whillier, "Evaluation of Flat Plate Solar Collector Performance," Transactions of the Conference on the use of Solar Energy: The Scientific Basis, Vol. II. Part 1, Section A. pp. 74-104 (1955).

S. A. Klein, "Calculation of Flat-Plate Collector Utilizability," Solar Energy 21, 393 (1978).

6. S. A. Klein and W. A. Beckmán, "A General Design Method for Closed-Loop Solar Energy Systems," Solar Energy 22, 269 (1979).

7. M. Collares-Pereira, A. Rab1, "Simple Procedure for Predicting Long-term Average Performance of Nonconcentrating and of Concentrating Solar Collectors," Solar Energy 23, 235 (1979).

8. M. Collares-Pereira, A. Rabl, "Derivation of Method for Predicting Long Term Average Energy Delivery of Solar Collectors," Solar Energy 23, 223 (1979).

9. J. A. Duffie and W. A. Beckman, Solar Energy Thermal Processes, Wiley, New York (1974). 
F. Kreith and J. F. Kreider, Principles of Solar Energy Engineering, McGraw-Hill, New York (1978).

10. E. D. Eason, "The Cost and Value of Washing Heliostats," Sandia Livermore Laboratories, Livermore, CA 94550, (1979).

11. M. Collares-Pereira and A. Rabl, Collector Comparison Based on. Yearly Average Performance, SERI/TR-304, presented at 1979 ISES Congress in Atlanta, GA.

12. "SOLMET, Volume 1-User's Manual TD-9724, Hourly Solar Radiation-Surface Meteorological Observations," National Climatic Center, Asheville, NC 28801 (1978).

13. C. M. Randall and M. E. Whitson, Jr, Final Report, Hourly Insolation and Mctcorologica1 Data Baoco Including Improved Dircct Inoolation Eotimatc3. Aerospace Corporation Rep. No. ATR-78 (7592-1) E1 Segundo, CA 90245, (1978).

14. R. Winston, "Solar Concentrators of a Novel Design," Solar Energy 16, 89 (1974).

15. A. Rabl, "Comparison of Solar Concentrators," Solar Energy 18, 93 (1976).

16. P. J. Eicker, Sandia Livermore Laboratories, letter of 18 April 1979 to J. Thornton, SERI.

17. J. E. Hay, "Measurement and Modeling of Shortwave Radiation on Inclined Surfaces." 3rd Conf. Atmos. Rad., pp. 28-30, June 1978, Davis, CA, published by American Meteorological Society, Boston, MA.

18. A. Rab1, J. O'Gallagher, and R. Winstun, "Designt and Tesl uf Nunevacuated Solar Collectors with Compound Parabolic Concentrators," Solar Energy 25, 335 (1980).

19. H. W. Gaul and A. Rabl, "Incidence Angle Modifier and Average Optical Efficiency of Parabolic Trough Collectors," Transactions of the ASME J. of Solar Energy Engineering, Vol. 102, 16(1980).

20. P. Bendt and A. Rab1, Effect of Circumsolar Radiation on Performance of Focusing Collectors, SERI/TR-34-093 (1980), to be published in Transactions of the ASME, J. of Solar Energy Engineering.

21. P. I. Cooper and R. V. Dunkle,"A Nonlinear Flat-Plate Collector Mode1," to be published in Solar Energy.

22. Beckman, W. A. "Duct and Pipe Losses in Solar Energy Systems." Solar Energy 21, 53 (1978).

23. V. E. Dudley and R. M. Workhoven, Summary Report: Concentrating Solar Collector Test Results Collector Module Test Facility. Albuquerque, NM: Sandia Labs.; SAND-78-0977 (1979). 
24. Caputo, R., The Evolving Role of Solar Thermal Electric Power, Informal Report, Jet Propulsion Laboratory, 1979 IOM 311.8-049, April; and personal communication.

W. D. Metz, "Energy Storage and Solar Power: An Exaggerated Problem." Science 200, 1471 (1978).

26. M. Collares-Pereira, "High Temperature Solar Collector with Optimal Concentration-Non-Focussing Fresnel Lens with Secondary Concentrator," Solar Energy 23, 409 (1979).

27. F. Schiller, "Mit der Dummhe1t kaempfen Goetter selbst vergebens," from "Die Jungfrau von Orleans," III, vi.

28. I. J. Hall, R. R. Prarie, H. E. Anderson and E. C. Boes, "Generation of Typical Meteorological Years for 26 SOLMET Stations," Report SAND 78-1601 (Albuquerque, NM, Sandia Laboratories, August 1978).

29. E. C. Boes et al., "Availability of Direct, Total and Diffuse Solar Radiation to Fixed and Tracking Collectors in the USA," Sandia Laboratories Report SAND-77-0885 (1977).

W. C. Dickinson, "Annual Available Radiation for Fixed and Tracking Co1lectors," Solar Energy 21, 249 (1978).

30. F. DeWinter, "Heat Exchanger Penalties in Double Loop Solar Water Heating Systems," Solar Energy 17, 335 (1975).

31. Note on Correlations for Central Receiver: The results for the central receiver vary strongly with optical design. The optical design in turn depends on many factors, in particular the geographic latitude, the relative cost of helfostats and the remainder of the plant, and whether the heliostat field surrounds the tower (typical design for large installations) or whether it lies to the north of the tower (typical design for small installations). Investigation of these points is beyond the scope of the present paper. We have only considered the incidence angle modifler in Table 2.-1; it rorresponds to a heliostat field which surrounds the tower and which is optimized for $35^{\circ}$ latitude.

32. L. L. Vant-Hull, personal communication.

33. J. O'Gallagher et al., "Optical Losses and Heat Transfer in an Evacuated Tubular Absorber Under 5X Nonimaging Concentration," Proceedings of the 1980 Annual Meeting of the American Section of the International Solar Energy Society, Phoenix, AZ, p. 605.

A. Rabl, "Optical and Thermal Analysis of Concentrators," Solar Thermal Concentrating Collector Technology Symposium, 14-15 June 1978, Denver, CO; SERI/TP-34-048 (1978).

"XE-300 Solar Energy Collector," Energy Design Corporation, 1756 Thomas Road, P. O. Box 34294, Memphis, Tennessee 38134 (1980). 


\section{S=Plo}


The correlation of Fig. 2-2 can be used for an evacuated tubular collector if 1ts Incidence angle modifies is close to the standard form, Eq. 2-4. In general the incidence angle modifier of tubular collectors may be quite different and it is necessary to evaluate the effect of variations of the incidence angle modifiers. To do this and to extend our method to the principal evacuated collectors sold in the United States today, we have repeated the flat-plate simulation using the incidence angle modifiers* of. Fig. A-1. instead of Eq. 2-4.

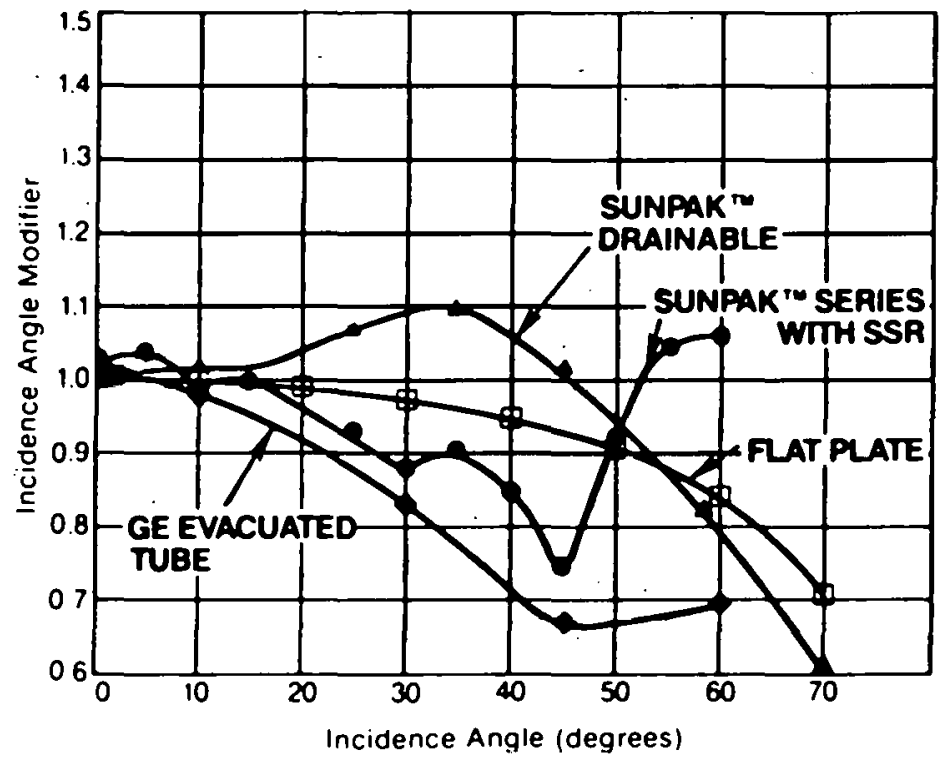

Figure A-1. Incidence Angle Modifiers for Several Evacuated-Tubular Collectors

(Incidence Angle in Direction Perpendicular to

Tubes.)

Figures $A-2$ to $A-4$ show the resulting correlations for the yearly collectible energy $Q$ for three of the collectors in Fig. A-l: the SUNPAK Series with SSR (labeled OWENS-ILLINOIS in Fig. A-2) the SUNPAK Drainable (1abeled SUNPAK DRAINABLE in Fig. A-3), and the GE Evacuated Tube (labeled GENERAL ELECTRIC in Fig. A-4). The rms errors between simulation and correlation are as small as for the FLAT PLATE, i.e., 2\%. Despite the large differences between the incidence angle modifiers, the resulting correlations are remarkably close to each other. The OWENS ILLINOIS curves are almost identical to those for the FLAT PLATE, and the others show differences on the order of $\pm 5 \%$. The

*This figure is taken from the brochure "A Pipeline to the Sun from. OwensIllinois, SUNPAK" number 13.11/0W, 1979, Owcno-Illinoic, Inc., Development Center, 1020 North Westwood, Toledn, OH 43607. 
precise shape of the incidence angle modifies does not appear to be critical for, the calculation of yearly average performance.

In fact, one obtains essentially the same result as Figs. A-2 to A-4 if one simply rescales the flat-plate correlation, Fig. 2-2, by the appropriate ratio of the a11-day average incidence angle modifiers. Since the incidence angle in Fig. $A-1$ is in the direction perpendicular to the tubes*, this correction factor is

$$
\overline{\mathrm{K}}=\int_{0}^{\pi / 2} \mathrm{~d} \theta \cos \theta \mathrm{K}(\theta)
$$

With this correction one can, therefore, use Figs. 2-2 to 2-6 even for collectors whose incidence angle modifier is very different from Eq. 2-4.

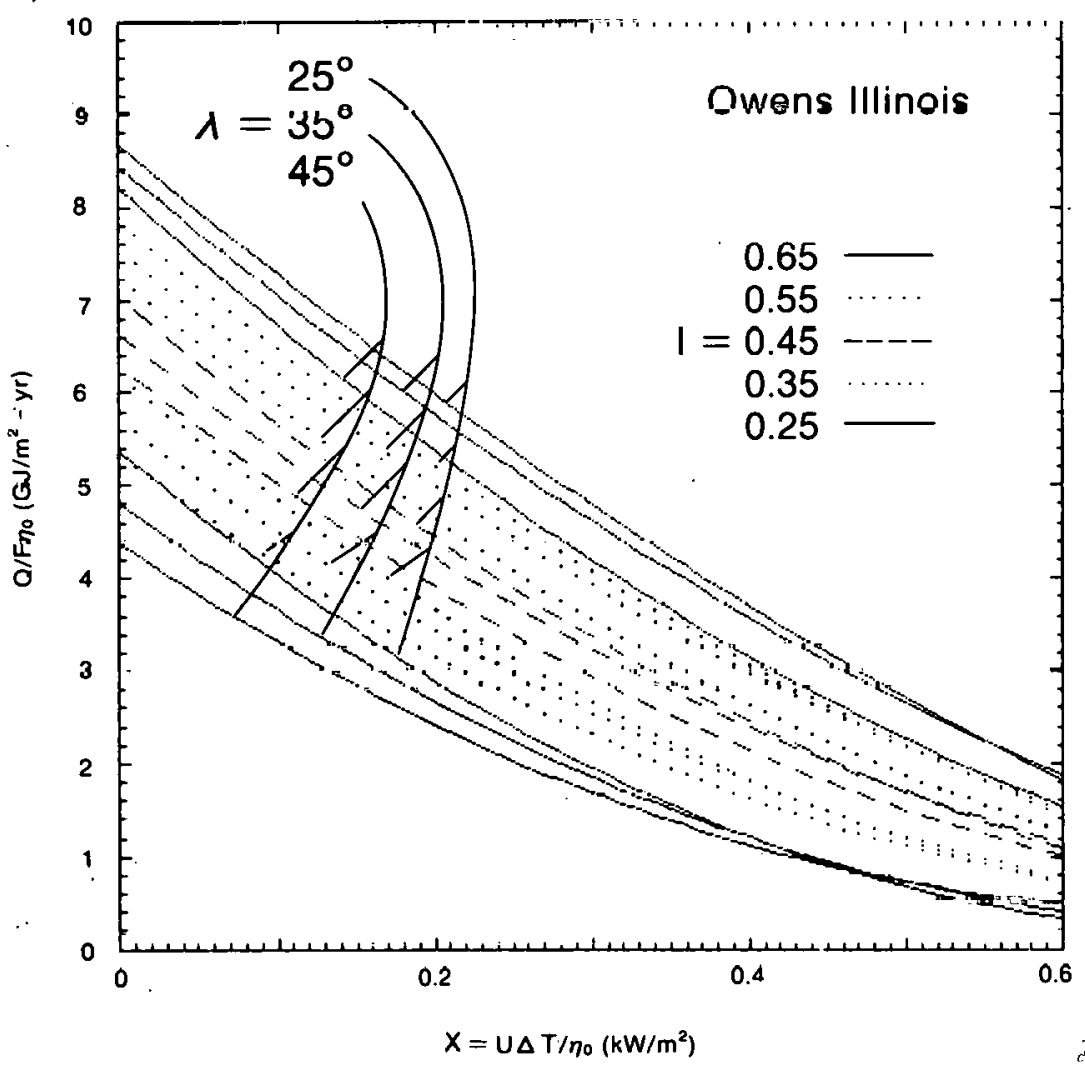

$$
\begin{aligned}
& \mathrm{Q} /\left(\mathrm{F} \mathrm{n}_{0}\right)=(6.402+4.373 \mathrm{I})+(-8.826+11.551 \mathrm{I}) \mathrm{L}+(4.058-6.223 \mathrm{I}) \mathrm{I}^{2}{ }^{2} \\
& +\left[(-29.356+16.529 \mathrm{I})+(44.001-42.120 \mathrm{I}) \mathrm{L}+(-22.704+9.562 \mathrm{I}) \mathrm{L}^{2}\right] \mathrm{X} \\
& +\left[(31.487-39.854 \mathrm{I})+(-57.797+80.311 \mathrm{I}) \mathrm{L}+(36.728-40.407 \mathrm{I}) \mathrm{L}^{2}\right] \mathrm{X}^{2}
\end{aligned}
$$

Figure A-2. Yearly Collectible Energy O for SUNPAK ${ }^{\text {TM }}$ SERIES with SSR, Shown as Graph and as Curve Fit for Q/(Fno), as Function of Threshold X (In $\mathrm{kW} / \mathrm{m}^{2}$ ), of Direct Normal Irradlance I (In $\mathrm{kW} / \mathrm{m}^{2}$ ) and of Latlude ( $A$ in Degrees, $L$ in Radlans).

\footnotetext{
*For a collector at tilt equal latitude with tubes running north-south, this means that the incidence angle for Fig. A-1 is in the equatorial plane.
} 


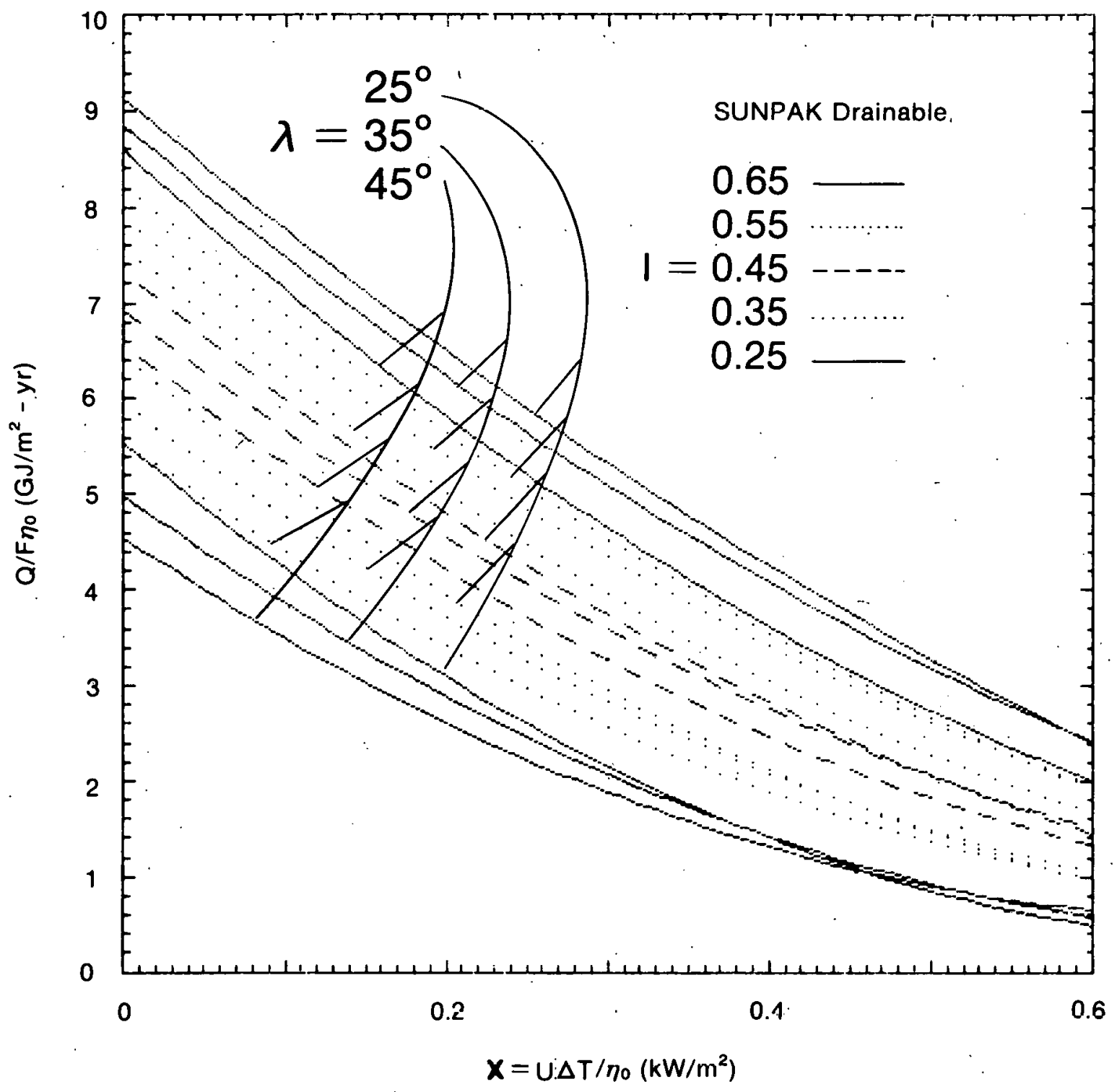

$\begin{aligned} \mathrm{Q} /(\mathrm{Fn} & \mathrm{O} \\ & =(5.909+6.149 \mathrm{I})+(-7.208+8.118 \mathrm{I}) \mathrm{L}+(2.855-3.868 \mathrm{I}) \mathrm{L}^{2} \\ & +\left[(-29.878+19.382 \mathrm{I})+(47.066-52.180 \mathrm{I}) \mathrm{L}+(-25.611+18.342 \mathrm{I}) \mathrm{L}^{2}\right] \mathrm{X} \\ & +\left[(32.957-46.537 \mathrm{I})+(-66.099+107.507 \mathrm{I}) \mathrm{L}+(44.358-64.103 \mathrm{I}) \mathrm{L}^{2}\right] \mathrm{X}^{2}\end{aligned}$

Figure A-3. Yearly Collectible Energy $Q$ for SUNPAK ${ }^{\text {TM }}$ DRAINABLE Shown as Graph and as Curve Fit for $Q /\left(F \eta_{0}\right)$ as Function of Threshold $X$ (in $\mathrm{kW} / \mathrm{m}^{2}$ ), of Direct Normal Irradiance I (in $\mathrm{kW} / \mathrm{m}^{2}$ ), and of Latitude ( $A$ in Degrees, $L$ in Radians). 


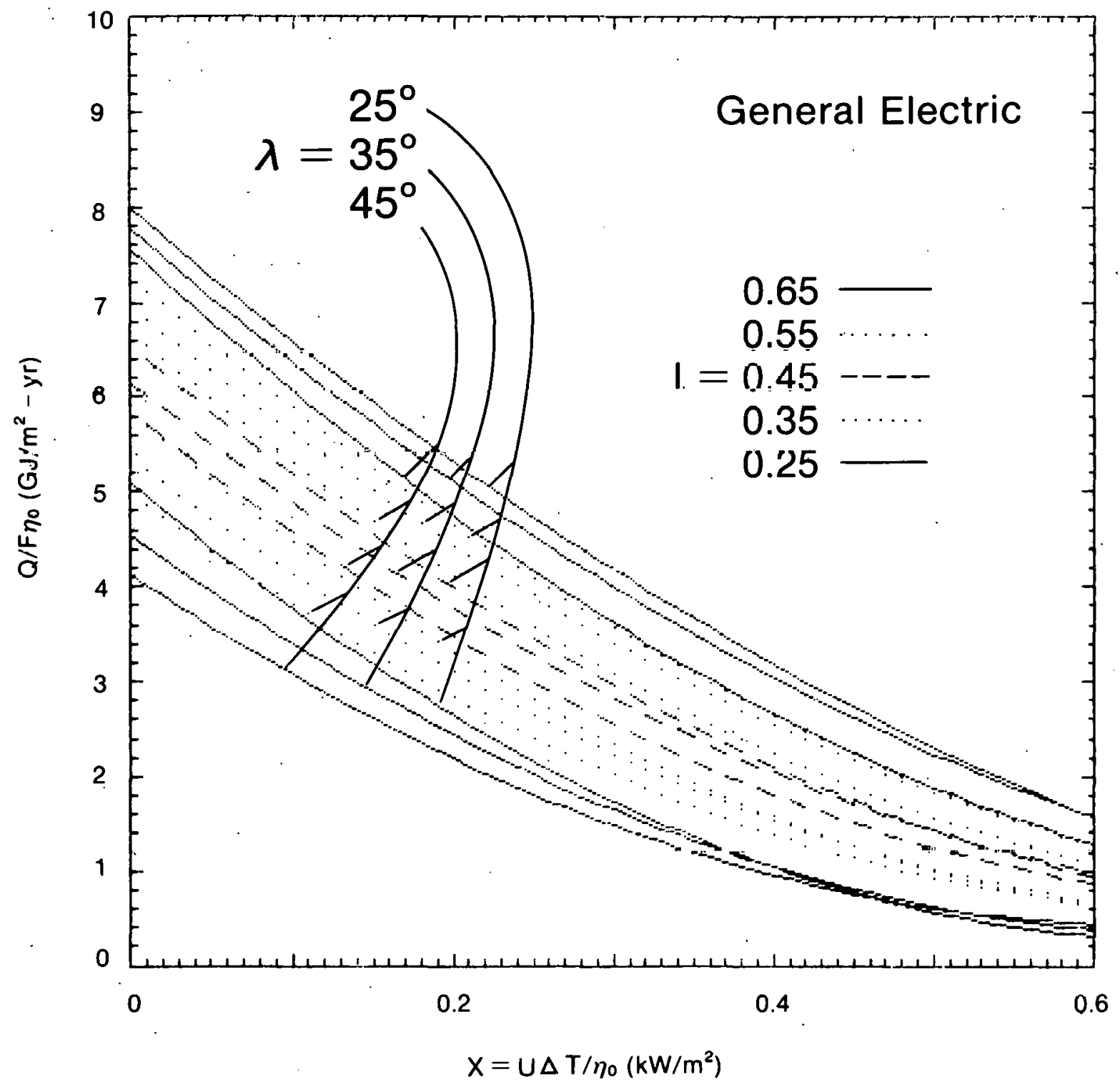

$$
\begin{aligned}
\mathrm{Q} /\left(\mathrm{Fn} \mathrm{O}_{\mathrm{O}}\right) & =(6.273+3.464 \mathrm{I})+(-8.480+11.169 \mathrm{I}) \mathrm{L}+(3.841-5.931 \mathrm{I}) \mathrm{L}^{2} \\
& +\left[(-30.051+19.080 \mathrm{I})+(46.740-53.216 \mathrm{I}) \mathrm{L}+(-24.993+19.070 \mathrm{I}) \mathrm{L}^{2}\right] \mathrm{X} \\
& +\left[(32.536+40.241 \mathrm{I})+(-60.339+89.176 \mathrm{I}) \mathrm{L}+(38.393-47.724 \mathrm{I}) \mathrm{L}^{2}\right] \mathrm{X}^{2}
\end{aligned}
$$

Figure A-4. Yearly Collectible Energy $Q$ for General Electric, Shown as Graph and as Curve Fit for $Q /\left(F \eta_{0}\right)$, as Function of Threshold $X$ (in $\mathrm{kW} / \mathrm{m}^{2}$ ), of Direct Normal Irradiance I (in $\mathrm{kW} / \mathrm{m}^{2}$ ), and of Latitude ( $A$ in Degrees, $L$ in Radians). 


\begin{tabular}{|c|c|c|}
\hline $\begin{array}{c}\text { Document Control } \\
\text { Page }\end{array}$ & $\begin{array}{l}\text { 1. SERI Report No. } \\
\text { TR-631-716 }\end{array}$ & 3. Recipient's Accession No. \\
\hline \multirow{2}{*}{\multicolumn{2}{|c|}{$\begin{array}{l}\text { 4. Title and Subtitle } \\
\text { Yearly Average Performance of the Principal Solar } \\
\text { Collector Types }\end{array}$}} & $\begin{array}{l}\text { 5. Publication Date } \\
\text { September } 1980\end{array}$ \\
\hline & & 6. \\
\hline \multicolumn{2}{|c|}{ 7. Author(s) Ari RabI } & 8. Performing Organization Rept. No. \\
\hline \multirow{2}{*}{\multicolumn{2}{|c|}{$\begin{array}{l}\text { 9. Performing Organization Name and Address } \\
\text { Solar Energy Research Institute } \\
\text { 1617 Cole Boulevard } \\
\text { Golden, Colorado } 80401\end{array}$}} & $\begin{array}{l}\text { 10. Project/Task/Work Unit No. } \\
3471.10 \\
\end{array}$ \\
\hline & & $\begin{array}{l}\text { 11. Contract (C) or Grant (G) No. } \\
\text { (C) } \\
\text { (G) }\end{array}$ \\
\hline \multirow{2}{*}{\multicolumn{2}{|c|}{ 12. Sponsoring Organization Name and Address }} & $\begin{array}{l}\text { 13. Type of Report \& Period Covered } \\
\text { Technical Report }\end{array}$ \\
\hline & & 14. \\
\hline
\end{tabular}

15. Supplementary Notes

16. Abstract (Limit: 200 words) The results of hour-by-hour simulations for 26 meteorological stations are used to derive universal correlations for the yearly total energy that can be delivered by the principal solar collector types: flat plate; evacuated tubes, CPC, single-and dual-axis tracking collectors, and central receiver. The cor relations are first-and second-order polynomials in yearly average insolation, latitude, and threshold (= heat loss/optical efficiency). With these correlations, the yearly collectible energy can be found by multiplying the coordinates of a single graph by the collector parameters, which reproduces the results of hour-byhour simulations with an accurancy (rms error) of $2 \%$ for flat plates and $2 \%-4 \%$ for concentrators. This method can be applied to collectors that operate year-around in such a way that no collected energy is discarded, including photovoltaic systems solar-augmented industrial process heat systems, and solar thermal power systems. The method is also recommended for rating collectors of different type or manufacturer by yearly average performance, evaluating the effects of collector degradation, the benefits of collector cleaning, and the gains from collector improvements (due to enhanced oprlcal efficiency or decreased heat loss per absorber surface). For most of these applications, the method is accurate enough to replace a system simulation.

17. Document Analysis

a. Descriptors Central Receivers ; Compound Parabolic Concentrator ; Data Compilation ; Evacuated Tube Collectors ; Flat Plate Collectors ; Insolation ; Performance:Q1 ; Performance Testing ; Simulation ; Solar Collectors ; Data ; Evacuated Collectors ; b. Identifiers/Open-Ended Terms Information; Numerical Data ; Solar Collectors ; Solar Concentrators ; Collectible Energy ; Dual Axis Tracking Collectors ; Single Axis Tracking Collectors

c. UC Categories

62

18. Availability Statement

National Technical Information Service

U.S. Department of Commerce

5285 Port Royal Road

Springfield, Virginia 22161

PuilI Nu. 8200-13 (0-79)

\begin{tabular}{|l|}
\hline 19. No. of Pages \\
47. \\
\hline 20. Price $\$ 4.50$ \\
\hline
\end{tabular}

